\title{
Development of an Orally Available and Central Nervous System (CNS)-Penetrant Toxoplasma gondii calcium-dependent protein kinase 1 (TgCDPK1) Inhibitor with Minimal Human Ether-à-go- go-Related Gene (hERG) Activity for the Treatment of Toxoplasmosis
}

\author{
Rama Subba Rao Vidadala ${ }^{\S}$, Kasey L. Rivas ${ }^{\ddagger}$, Kayode K. Ojo ${ }^{\ddagger}$, Matthew A. Hulverson ${ }^{\ddagger}$, \\ Jennifer A. Zambrisk ${ }^{\epsilon}{ }^{\epsilon}$, Igor Bruzual ${ }^{\Uparrow}$, Tracey L. Schultz ${ }^{\&}$, Wenlin Huang ${ }^{\dagger}$, Zhongsheng \\ Zhang $^{\dagger}$, Suzanne Scheele ${ }^{\#}$, Amy E. DeRocher ${ }^{\#}$, Ryan Choi ${ }^{\ddagger}$, Lynn K. Barrett ${ }^{\ddagger}$, Latha Kallur \\ Siddaramaiah ${ }^{\dagger}$, Wim G. J. Hol ${ }^{\dagger}$, Erkang Fan ${ }^{\dagger}$, Ethan A. Merrittt ${ }^{\dagger}$, Marilyn Parsons ${ }^{\#,}$, , Gail \\ Freiberg $^{\lambda}$, Kennan Marsh ${ }^{\lambda}$, Dale Kemp ${ }^{\lambda}$, Vern B. Carruthers ${ }^{\circledR}$, Nina Isoherranen ${ }^{\|}$, J. Stone \\ Doggett $\mid$, Wesley C. Van Voorhis ${ }^{\ddagger},{ }^{,}$, , and Dustin J. Maly ${ }^{\dagger},{ }^{*}$ \\ †Department of Biochemistry, University of Washington, Seattle, WA 98195, United States \\ ‡Department of Medicine, Division of Allergy and Infectious Diseases, and the Center for \\ Emerging and Re-emerging Infectious Diseases (CERID), University of Washington, Seattle, WA \\ 98109, United States \\ §Department of Chemistry, University of Washington, Seattle, WA 98195, United States \\ \#Center for Infectious Disease Research (formerly Seattle Biomedical Research Institute), Seattle, \\ WA 98109, United States \\ Department of Global Health, University of Washington, Seattle, WA 98195 United States \\ IPortland VA Medical Center, Portland, OR 97239, United States \\ €Paul G. Allen School for Global Animal Health, College of Veterinary Medicine, Washington State \\ University, Pullman, WA 99164, United States \\ \&Department of Microbiology and Immunology, University of Michigan Medical School, Ann Arbor, \\ MI 48109 United States \\ "Department of Pharmaceutics, University of Washington, Seattle, WA 98195, United States
}

\footnotetext{
Corresponding Authors: For Dustin J. Maly: phone, 206-543-1653; fax, 206-685-7002; maly@ chem.washington.edu. For Wesley C. Van Voorhis: phone, 206-543-2447, fax, 206-616-4898, wesley@uw.edu.

Supporting Information Available: IC 50 values of compounds $\mathbf{3 2}$ and $\mathbf{3 3}$ for human kinases; crystallographic data; synthesis and characterization data for all intermediate compounds; biological assay procedures; aqueous solubility assays; NMR spectra for final compounds; This material is available free of charge via the internet at http://pubs.acs.org.

Accession Codes

The PDB code for the X-ray crystallographic structure of compound $\mathbf{3 3}$ bound to wild type T.gondii CDPK1 is 4TZR and compound $\mathbf{1}$ bound to wild type T.gondii CDPK1 is 3SX9.

Notes

The authors declare the following competing financial interest: Gail Freiberg, Kennan Marsh, and Dale Kempf are employees of Abbvie.
} 
$\lambda$ AbbVie, N. Chicago, Illinois 60064, United States

\section{Abstract}

New therapies are needed for the treatment of toxoplasmosis, which is a disease caused by the protozoan parasite Toxoplasma gondii. To this end, we previously developed a potent and selective inhibitor (compound 1) of Toxoplasma gondii calcium-dependent protein kinase 1 (TgCDPK1) that possesses anti-toxoplasmosis activity in vitro and in vivo. Unfortunately, $\mathbf{1}$ has potent human Ether-à-go-go-Related Gene (hERG) inhibitory activity, associated with long Q-T syndrome, and, consequently, presents a cardiotoxicity risk. Here, we describe the identification of an optimized TgCDPK1 inhibitor 32, which does not have a hERG liability and possesses a favorable pharmacokinetic profile in small and large animals. 32 is CNS-penetrant and highly effective in acute and latent mouse models of $T$. gondii infection, significantly reducing the amount of parasite in the brain, spleen, and peritoneal fluid and reducing brain cysts by $>85 \%$. These properties make 32 a promising lead for the development of a new anti-toxoplasmosis therapy.

\section{Graphical abstract}

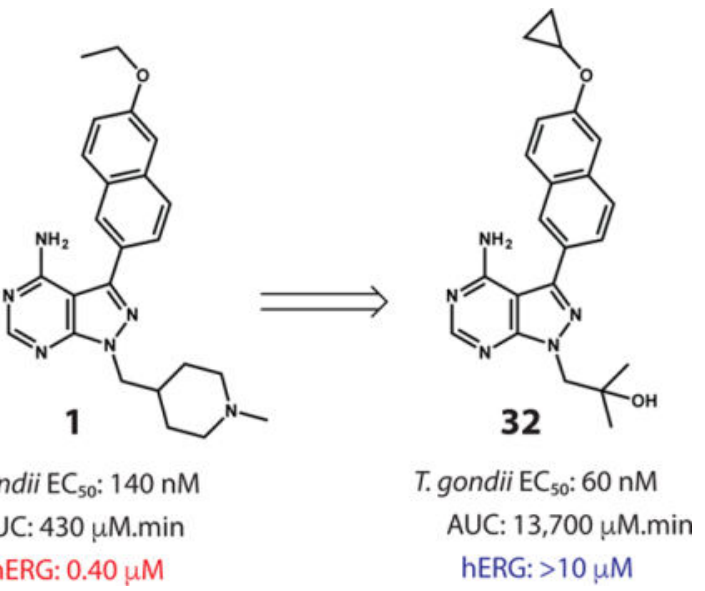

\section{Introduction}

Toxoplasmosis is an infectious disease that results from the infection of the protozoan parasite Toxoplasma gondii. ${ }^{1}$ While cats are the definitive host of $T$. gondii, this zoonotic parasite is estimated to be one of the most prevalent in humans, with approximately 30-50\% of the world's population being seropositive. ${ }^{2} T$. gondii infections of humans can be caused by the consumption of undercooked meat containing tissue cysts or by the accidental ingestion or inhalation of oocysts from cat feces. ${ }^{1,3} \mathrm{~T}$. gondii parasites rapidly proliferate during acute infection before being controlled by the immune system in immunocompetent individuals. ${ }^{4}$ However, despite this robust immune response, the $T$. gondii parasite is not eliminated. Instead, the parasite transforms into a slowly dividing cellular stage called the bradyzoite, which cluster into tissue cysts mainly located in the brain, eyes, and striated muscle. ${ }^{5}$ Tissue cysts can persist for the lifetime of the host; periodically rupturing and releasing tachyzoites that can again rapidly replicate and reform cysts. While in immunocompetent individuals toxoplasmosis is usually asymptomatic and recovery occurs 
in the absence of antibiotic treatment, $T$. gondii infection can sometimes trigger severe retinal diseases, which has been recently recognized to be particularly prevalent in regions of South America ${ }^{6,7}$ When T. gondii infection occurs during pregnancy, vertical transmission can ensue, resulting in birth defects or miscarriage. ${ }^{8}$ For individuals with compromised immune systems, active $T$. gondii infection primarily leads to encephalitis or chorioretinitis, but may cause disease in other organs as well. ${ }^{9}$

Current first-line therapy for toxoplasmosis involves treatment with a combination of pyramethamine and sulfadiazine, which inhibit the folate pathway in $T$. gondii. ${ }^{10}$ However, this therapeutic regimen requires long dosing periods and can be limited by rash, leukopenia, nephrotoxicity, teratogenicity, and kernicterus in newborns. ${ }^{11}$ There is a longstanding need for better toxoplasmosis drugs, especially therapeutic agents that are non-toxic, nonteratogenic, and with simple dosing profiles.

In order to develop new therapies for the treatment of toxoplasmosis, we and others have explored strategies that involve inhibiting enzymatic components of calcium-dependent cellular processes in the parasite, which are necessary for invasion into and egress from host cells. $T$. gondii calcium-dependent protein kinase 1 ( $T g \mathrm{CDPK} 1)$ is a particularly promising target due to its role in gliding and motility. ${ }^{12}$ Gliding and motility are necessary for $T$. gondii invasion and egress, and as T. gondii is an obligate intracellular parasite that requires these processes to proliferate, inhibition of $T g \mathrm{CDPK} 1$ represents a promising new antiparasitic strategy. Indeed, genetic or pharmacological disruption of $T g C D P K 1$ function blocks parasite growth in vitro and is able to prevent and treat established T. gondii infections in mice. ${ }^{13-20}$

We previously developed a number of highly promising pyrazolopyrimidine (PP)-based ATP-competitive inhibitors that are able to potently block the enzymatic activity of $T g$ CDPK1. These selective $T g$ CDPK1 inhibitors are able to block the invasion of $T$. gondii into host cells, preventing proliferation of the parasite. ${ }^{15,19,20}$ Recently, we have demonstrated that the $T g C D P K 1$ inhibitor 1 (1294) is an orally available inhibitor that possesses anti-toxoplasmosis activity in vitro and in vivo, with no apparent signs of toxicity. ${ }^{15}$ Furthermore, $\mathbf{1}$ was able to block vertical transmission of Neospora caninum in a pregnant mouse model, and since $N$. caninum is closely related to $T$. gondii, it speaks to a potential therapeutic application for toxoplasmosis in pregnancy. ${ }^{21,22}$ Unfortunately, we have found that $\mathbf{1}$ has potent human Ether-à-go-go-Related Gene (hERG) inhibitory activity $^{23}$-associated with long Q-T syndrome-and, thus, presents a significant cardiotoxicity risk in humans. ${ }^{24}$ Here, we describe the identification of optimized PP-based $T g$ CDPK1 inhibitor 32, which does not have an hERG liability but possesses the favorable anti-parasitic activity of lead compound $\mathbf{1}$.

\section{Results and Discussion}

\section{Molecular Design and Synthesis}

$T g$ CDPK 1 contains a $C$-terminal calcium-binding domain of 4 EF-hands (CDPK activation domain) linked to an $N$-terminal kinase domain. The ATP-binding cleft of $T g C D P K 1$, which is the site of interaction with PP-based inhibitors, is similar in structure to mammalian 
protein kinases with the exception that it contains a rare glycine residue at the gatekeeper position. The starting point for this study was compound $\mathbf{1}$, which is based on a PP scaffold that forms two hydrogen-bonding interactions with the hinge region of $T g C D P K 1$ (Figure 1). The C-3 $\left(\mathrm{R}_{1}\right)$ position of $\mathbf{1}$ is derivatized with a bulky 6-ethoxy-2-naphthyl group that occupies a hydrophobic pocket adjacent to TgCDPK1's glycine gatekeeper residue. As glycine is a very uncommon gatekeeper residue, the space occupied by the 6-ethoxy-2naphthyl group provides a means to obtain high selectivity over mammalian kinases, which often have larger gatekeepers that constrain access to the hydrophobic back pocket. The 6alkoxy-2-naphthyl substitution pattern appears to be optimal for complementing the hydrophobic gatekeeper pocket of $T g$ CDPK1 and enhancing overall inhibitor selectivity. At the N-1 position, 1 contains an $N$-methyl-4-piperidinemethylene group, directed toward the sugar pocket. This basic group increases potency for $T g \mathrm{CDPK} 1$ and, in combination with 6alkoxy-2-naphthyl substituents at the $\mathrm{C}-3\left(\mathrm{R}_{1}\right)$ position, the 4-piperidinemethyl group greatly enhances kinase selectivity. ${ }^{25}$

Several synthetic strategies were used to generate derivatives of $\mathbf{1}$. The synthetic route shown in Scheme 1 was used to generate inhibitors that contain a 6-ethoxy-2-naphthyl group at the $\mathrm{R}_{1}$ position and various 4-piperidinemethylene or 3-azetidinemethylene derivatives at the $\mathrm{R}_{2}$ position (Table 1). Inhibitors that contain an $N$-methyl-4-piperidinemethylene $\mathrm{R}_{2}$ group and various 6-alkoxy-2-naphthyl or 6-alkoxy-2-quinolinyl groups at the $\mathrm{R}_{1}$ position were generated by either alkylation of $t$-butyl-4-((4-amino-3-(6-hydroxynaphthalen-2yl)-1 $H$-pyrazolo[3,4- $d$ ]pyrimidin-1-yl)methyl)piperidine-1-carboxylate, followed by Boc deprotection and reductive alkylation, or by palladium-catalyzed Suzuki-Miyaura couplings between appropriate aryl boronic acids and boronate esters and $t$-butyl-4-((4-amino-3iodo-1 $H$-pyrazolo[3,4- $d$ ] pyrimidin-1-yl)methyl)piperidine-1-carboxylate, followed by Boc deprotection and reductive alkylation (Scheme 2). Boronic esters and boronic acids that are not commercially available were prepared from aryl bromides using standard methods. ${ }^{26}$ Compounds containing variable groups at the $\mathrm{R}_{2}$ position were generated by alkylating 3iodo- $1 H$-pyrazolo[3,4- $d$ ]pyrimidin-4-amine with alkyl halides, alkyl mesylates, or expoxides followed by Suzuki-Miyaura coupling to $\mathrm{R}_{1}$-boronic acids or boronate pinacol esters (Scheme 3).

\section{Inhibitor Testing Cascade}

A multi-assay testing cascade was used to determine if newly generated analogs demonstrated superior anti-parasitic properties compared to compound 1. Compounds were first tested for the ability to block the activity of recombinant $T g C D P K 1$ using a luminescence-based assay that measures the consumption of ATP in the presence of the peptide substrate Syntide $2 .{ }^{19}$ All assays were performed in the presence of $2 \mathrm{mM} \mathrm{CaCl}_{2}$ and at an ATP concentration-10 $\mu \mathrm{M}$-equal to TgCDPK1's Michaelis constant $\left(\mathrm{K}_{\mathrm{m}}\right)$. Compounds of sufficient in vitro enzyme inhibitory activity were then tested for their ability to block the invasion and growth of parasites into human foreskin fibroblast cells using a previously described T. gondii cellular assay. ${ }^{19}$ Inhibitors with comparable in vitro enzymatic and cellular potencies as $\mathbf{1}$, were next screened for selectivity in two assays. To determine selectivity for $T g C D P K 1$ over mammalian kinases, compounds were tested against the tyrosine kinase Src, which is representative of the most likely off targets of 
pyrazolopyrimidine-based inhibitors that contain a large aryl group at the C-3 $\left(\mathrm{R}_{1}\right)$ position due to its small threonine gatekeeper residue. ${ }^{27}$ General off target toxicity was determined by testing for growth inhibition $\left(\mathrm{GI}_{50}\right)$ of two mammalian cell lines, HepG2 (liver) and CRL-8155 (lymphoblast). As elimination of hERG activity was a major goal of this study, all compounds with favorable profiles were tested for hERG activity using a previously described assay. ${ }^{23,28,29}$

In generating analogs of $\mathbf{1}$, we felt that it would be important to retain a 6alkoxynaphthalen-2-yl group at the C-3 $\left(\mathrm{R}_{1}\right)$ position. In addition, due to the unexpected contribution of the 4-piperidinemethyl group to inhibitor potency and selectivity, ${ }^{25}$ compounds that contain a similar substituent at the $\mathrm{R}_{2}$ position were focused on first. Results for compounds containing a fixed 6-ethoxynaphthyl at the $\mathrm{R}_{1}$ position and various 4piperidinemethyl or 3-azetidinemethyl groups at the $\mathrm{R}_{2}$ position are shown in Table 1 . Increasing the size of the $\mathrm{N}$-alkyl group on the 4-piperidinemethyl moiety (7) resulted in slightly reduced target potency and did not diminish hERG inhibition. Replacing the 1methylpiperidin-4-ylmethyl group of $\mathbf{1}$ with either a 3-azetidinemethyl (5) or a 1-methyl-3azetidinemethyl (6) group resulted in potent inhibition of $T g C D P K 1$, albeit with attenuated activity against parasite proliferation, but only a slight decrease in hERG inhibition. However, an analog containing an acetylated 4-piperidinemethyl group (inhibitor 8) displayed acceptable levels of inhibition of the TgCDPK1 enzyme and parasite proliferation with no hERG activity. Inhibitor 9, which contains a 1-acetyl-3-azetidinemethylene group instead of a 1-acetyl-4-piperidinemethyl moiety, also lacks hERG activity but possesses unacceptably low activity in the $T$. gondii cellular assay. These results are consistent with the observed correlation between inhibitor basicity and hERG inhibition. ${ }^{30-32}$

We next explored whether hERG inhibition could be reduced in analogs of 1 that maintain the 1-methyl-4-piperidinemethyl group by modifying the $N-1$ position $\left(\mathrm{R}_{2}\right)$ of the pyrazolopyrimidine scaffold (Table 2). For the 6-alkoxynaphthalen-2-yl series, inhibitors containing cycloalkyloxy groups larger than ethyl (10-12) were potent $T g C D P K 1$ inhibitors and were of reasonable potency in the $T$. gondii cellular assay. However, the hERG activity of these compounds was comparable to $\mathbf{1}$. Unfortunately, introduction of more polar groups at the 6 position of the naphthyl ring (13-16), which reduces overall inhibitor lipophilicity and would be expected to diminish hERG activity, led to less potent inhibition of TgCDPK1 and subsequent reduced potency in the $T$. gondii cellular assay. A more favorable inhibitor profile was obtained by replacing the 6-ethoxy-2-naphthyl group of $\mathbf{1}$ with a 2ethoxyquinolin-6-yl moiety (17). Inhibitor 17 showed comparable levels of $T g C D P K 1$ enzyme inhibition and efficacy in the invasion assay as $\mathbf{1}$, with no detectable Src inhibition or mammalian cell toxicity. Compound $\mathbf{1 7}$ also possesses 25 -fold lower activity against hERG than 1. However, replacing the ethyl group of $\mathbf{1 7}$ with more hydrophobic substituents, like trifluoroethyl (18) or cyclopropyl (19), led to unacceptable levels of hERG inhibition (Table 2).

Finally, we investigated whether the cyclic amine substituent at the $\mathrm{R}_{2}$ position of $\mathbf{1}$ can be replaced with another group that confers similar potency, selectivity, and solubility. We have previously shown that inhibitors possessing $\mathrm{R}_{2}$ groups that are connected to the $N-1$ position of the PP scaffold through a methylene linkage demonstrate the highest degree of selectivity 
for $T g \mathrm{CDPK} 1$ over mammalian kinases with small gatekeepers, like the tyrosine kinases Src and Abl. ${ }^{25}$ Therefore, a panel of analogs with variable $\mathrm{R}_{2}$ groups, which extend into the ribose-binding pocket of the ATP-binding site was generated (Table 3). In general, inhibitors of this class are potent inhibitors of the $T g C D P K 1$ enzyme and efficacious in the $T$. gondii cellular assay. Furthermore, all of the inhibitors in Table 3 are highly selective (>150-fold) for $T g C D P K 1$ over Src. Consistent with basicity at the $\mathrm{R}_{2}$ position playing a major role in hERG inhibition, inhibitor $\mathbf{2 0}$, which contains a dimethylamino group at the $\mathrm{R}_{2}$ position, has a similar level of hERG activity as $\mathbf{1}$. Compounds $\mathbf{2 1 - 2 3}$, which all contain an isobutyl group at the $\mathrm{R}_{2}$ position, are potent inhibitors of the $T g \mathrm{CDPK} 1$ enzyme and are at least as effective as 1 against the parasite. Importantly, these compounds are $>3500$-fold selective for $T g$ CDPK1 over Src, demonstrate no detectable growth inhibition of HepG2 and CRL-8155 cells, and lack hERG activity. Compounds 24-29, which all contain a cycloalkyl ether group linked to the $N-1\left(\mathrm{R}_{2}\right)$ position through a methylene, are also effective inhibitors of $T g \mathrm{CDPK} 1$ and parasite proliferation. All of these compounds, except 28, have an $\mathrm{IC}_{50}>10$ $\mu \mathrm{M}$ for Src activity and do not inhibit the growth of mammalian cells. Furthermore, all of the inhibitors in this series, except $\mathbf{2 4}\left(\mathrm{IC}_{50}=1.9 \mu \mathrm{M}\right)$, have an $\mathrm{IC}_{50}$ of greater than $10 \mu \mathrm{M}$ for hERG activity. Inhibitors 30-36, which either contain a 2-methylpropan-2-ol or a 2,2dimethylpropan-1-ol group at the $\mathrm{R}_{2}$ position also possess desirable profiles: potent $T g C D P K 1$ enzyme inhibition, effective inhibition of parasite proliferation, and no detectable off-target inhibition or toxicity.

\section{Pharmacokinetic Profiling of Potent and Selective TgCDPK1 Inhibitors}

Based on the abilities of a number of inhibitors to potently block $T$. gondii proliferation in mammalian cells, while demonstrating little or no off-target toxicity or hERG inhibition, we next prioritized compounds based on their solubility in water and pharmacokinetic (PK) properties (Table 4). The aqueous solubility of inhibitors $8,17,29,31-34$, and 35 was determined at $\mathrm{pH}=6.5$. The initial $\mathrm{PK}$ profiles of these inhibitors were determined after a single $10 \mathrm{mg} / \mathrm{kg}$ oral dose in three Balb/c mice, with sampling conducted at the time points indicated in the Experimental Section. As a reference, after a $10 \mathrm{mg} / \mathrm{kg}$ per os (PO) dose, lead inhibitor 1 demonstrated a maximum concentration $\left(\mathrm{C}_{\max }\right)$ of $0.75 \pm 0.15 \mu \mathrm{M}$ and total exposure (area under the plasma concentrations versus time curve, AUC) of $430 \pm 84$ $\mu \mathrm{M} \cdot \mathrm{min}$. Inhibitors $\mathbf{2 9}, \mathbf{3 4}$, and $\mathbf{3 5}$ were poorly soluble $(<20 \mu \mathrm{M})$ relative to $\mathbf{1}$ (solubility = $82 \mu \mathrm{M})$ and all three compounds had lower exposures and higher clearances than $\mathbf{1}$. Inhibitors $\mathbf{8}$ and $\mathbf{1 7}$ demonstrated better solubility but also had a lower exposure and higher clearance than $\mathbf{1}$, which is likely due to the more efficient metabolism of these compounds. In contrast, inhibitors 31-33, which all contain a 2-methylpropan-2-ol at the $\mathrm{R} 2$ position, were highly soluble and $\mathbf{3 2}$ and $\mathbf{3 3}$ reached maximum serum concentrations $\left(\mathrm{C}_{\max }\right)>10$-fold higher and total exposure $>30$-fold higher than $\mathbf{1}$ (Table 4 and Figure 2). Compound $\mathbf{3 1}$ was absorbed rapidly with a $\mathrm{T}_{\max }$ of $50 \mathrm{~min}$ and a $\mathrm{C}_{\max }$ nearly 10 -fold higher than $\mathbf{1}$. Yet, the overall exposure of $\mathbf{3 1}$ was only twice as high as $\mathbf{1}$ and much lower than $\mathbf{3 2}$ and $\mathbf{3 3}$. Based on this mouse pharmacokinetic data, compounds $\mathbf{3 2}$ and $\mathbf{3 3}$ were selected for further pharmacokinetic and tolerability studies. 


\section{Dose Finding and Tolerability of 32 and 33}

Based on the PK parameters of $\mathbf{3 2}$ and $\mathbf{3 3}$ following single dose administration to mice, these compounds were evaluated for tolerability following escalated dosing. Both compounds were initially dosed at $10 \mathrm{mg} / \mathrm{kg}$ on day one. As no observable adverse effects were detected in mice dosed with either $\mathbf{3 2}$ or 33 , the next dose was increased to $50 \mathrm{mg} / \mathrm{kg}$ on day 4 , followed by a final dose of $100 \mathrm{mg} / \mathrm{kg}$ on day 8 . Mice showed no overt signs of toxicity or weight loss over the 10-day observation period. Next, the plasma protein binding of both compounds was evaluated. Both compounds were highly protein bound in mouse plasma with plasma protein binding of $96 \%$ for $\mathbf{3 2}$ and $88 \%$ for $\mathbf{3 3}$. Based on the protein binding values the plasma concentrations required to maintain unbound plasma exposure above the $T g \mathrm{CDPK} 1 \mathrm{EC}_{50}$ are $1.33 \mu \mathrm{M}$ for $\mathbf{3 3}$ and $1.5 \mu \mathrm{M}$ for 32. Using these target concentrations and the single dose PK data, a multiple dosing regimen with a loading dose of $20 \mathrm{mg} / \mathrm{kg}$ of $\mathbf{3 2}$ and $\mathbf{3 3}$ followed by a $5 \mathrm{mg} / \mathrm{kg}$ daily dose for five days was evaluated. Blood was collected at multiple time points to determine plasma concentrations over the course of treatment (Figure 3). Both compounds demonstrated excellent exposure through the 24-hour dosing interval with the trough concentrations remaining $>1.5 \mu \mathrm{M}$ throughout the study. The measured concentrations following multiple dosing were similar to those predicted from the single dose PK studies in mice (Figure 3). Neither compound showed any evident signs of toxicity compared to mice dosed with vehicle only. Cardiac puncture blood collection was performed at the end of the study for complete blood count and serum biochemical profiles. All results were reported by Phoenix Central Laboratory to be within a normal range for species and age.

In a second multiple dose study compound $\mathbf{3 2}$ was administered at $50 \mathrm{mg} / \mathrm{kg}$ PO every other day for 5 doses and compound $\mathbf{3 3}$ was administered with a $20 \mathrm{mg} / \mathrm{kg}$ loading dose followed by a $10 \mathrm{mg} / \mathrm{kg}$ maintenance dose every other day for 5 doses. The exposure to $\mathbf{3 3}$ with this dosing regimen was similar to the one observed with daily dosing of the lower dose and the plasma concentration at various time points were well predicted based on the single dose PK results. With compound 32 plasma concentrations remained $>10 \mu \mathrm{M}$ for the entire duration of the study (Figure 3 ) with maximum concentrations reaching $43 \mu \mathrm{M}$. The exposure to compound 32 following the last $50 \mathrm{mg} / \mathrm{kg}$ dose was higher than predicted from single dose studies with longer half-life suggesting possible saturation of metabolism at this dose.

Based on the favorable single and multiple dose PK and the lack of observable toxicity, compounds $\mathbf{3 2}$ and $\mathbf{3 3}$ were evaluated for tolerability and PK characteristics in rats following intravenous (IV) and PO dosing. Following IV administration to rats both $\mathbf{3 2}$ and $\mathbf{3 3}$ displayed biphasic kinetics with compound $\mathbf{3 3}$ reaching distribution equilibrium more rapidly than $\mathbf{3 2}$ (Figure 4). Compound $\mathbf{3 2}$ distributed approximately to total body water with a volume of distribution at steady state $\left(\mathrm{V}_{\mathrm{ss}}\right)$ of $0.9 \mathrm{~L} / \mathrm{kg}$. The distribution of $\mathbf{3 3}$ was more extensive with a $\mathrm{V}_{\mathrm{ss}}$ of $5.8 \mathrm{~L} / \mathrm{kg}$. Both compounds had very low systemic clearances in rats but, in contrast to mice, the clearance of $\mathbf{3 3}$ was 4 -fold higher than that of $\mathbf{3 2}$. The elimination half-lives of both compounds were acceptable for multiple dosing regimens, 9.6 and 13 hours for $\mathbf{3 2}$ and 33, respectively (Figure 4). 
Following oral administration to rats both compounds showed slow absorption with absorption phase continuing for 12 hours after oral dosing. The plasma concentrations over the 24-hour period after PO dosing exceeded those observed after IV dosing (Figure 4) suggesting that both $\mathbf{3 2}$ and $\mathbf{3 3}$ had essentially complete bioavailability in rats. The apparent bioavailability of these compounds was greatly improved compared to that of compound 1 $(46 \%)$.

Because it is important that anti-toxoplasmosis therapies are able to prevent reactivation of parasites within tissue cysts, which largely reside in the central nervous system (CNS), the distribution of compounds $\mathbf{3 2}$ and $\mathbf{3 3}$ to the brain was next determined. To do this, the distribution of $\mathbf{3 2}$ and $\mathbf{3 3}$ into mouse brain $(\mathrm{n}=3)$ at one hour after intraperitoneal dosing of 5 $\mathrm{mg} / \mathrm{kg}$ was measured. The mean concentration of compound $\mathbf{3 2}$ at one hour in brain was 1.2 $\pm 0.5 \mu \mathrm{M}$, a concentration well above the $T g \mathrm{CDPK} 1 \mathrm{EC}_{50}$. The corresponding plasma concentration of $\mathbf{3 2}$ was $4.1 \pm 1.1 \mu \mathrm{M}$ resulting in a brain to plasma concentration ratio of $\mathbf{3 2}$ of $0.33 \pm 0.22$. This brain penetration was comparable to $1(0.31)$. In accordance with the larger distribution volume of compound $\mathbf{3 3}$, it demonstrated a greater brain to plasma concentration ratio (1.65 \pm 0.84$)$. Both the brain and plasma concentration of 33, $1.90 \pm 0.24$ $\mu \mathrm{M}$ and $1.23 \pm 0.76 \mu \mathrm{M}$, respectively, were above the $T g \mathrm{CDPK} 1 \mathrm{EC}_{50}$. As both $\mathbf{3 2}$ and $\mathbf{3 3}$ provide adequate exposure in CNS, they are both excellent candidates for animal efficacy models of toxoplasmosis.

\section{Selectivity Profiling of 32 and 33}

Due to the impressive PK properties of $\mathbf{3 2}$ and $\mathbf{3 3}$, these inhibitors were profiled further. To demonstrate that $T g C D P K 1$ is the kinase target of these compounds in $T$. gondii, compounds $\mathbf{3 2}$ and $\mathbf{3 3}$ were tested against parasitic cell lines overexpressing the Gly128Met $T g$ CDPK1 gatekeeper mutant or wildtype (wt) $T g$ CDPK1. Expression of the Gly128Met gatekeeper mutant of $T g$ CDPK1, but not wt $T g C D P K 1$, makes $T$. gondii highly resistant to PP-based inhibitors that contain 6-alkoxynaphthalen-2-yl groups at the $\mathrm{R}_{1}$ position. ${ }^{19,33}$ Both $\mathbf{3 2}$ and 33 show a dramatic loss in potency against parasites overexpressing the Gly128Met gatekeeper mutant relative to the parent $\mathrm{RH}$ strain and to $T$. gondii overexpressing wild type $T g$ CDPK1 (Figure 5), which is consistent with $T g$ CDPK1 being the primary target through which these inhibitors exert their anti-parasitic effects.

$\mathbf{3 2}$ and $\mathbf{3 3}$ were further profiled for any mammalian kinase off targets using a panel of 80 human kinases representing different subfamilies of the kinome tree with a fluorescencebased competition assay (Supporting Information Table 1). ${ }^{17} 78$ of the 80 mammalian kinases tested have an $\mathrm{IC}_{50}>1.5 \mu \mathrm{M}(>1500$-fold selective for $T g \mathrm{CDPK} 1)$ for 32. For the two kinases-PKC $v$ (PKD3) and MEK1-that have sub-micromolar $\mathrm{IC}_{50}$ values, compound 32 is a $>120$-fold and $>900$-fold less potent inhibitor than for $T g$ CDPK1, respectively. Compound $\mathbf{3 3}$ appears to be slightly more selective than compound $\mathbf{3 2}$. Indeed, it demonstrated an $\mathrm{IC}_{50}$ value of greater than $5 \mu \mathrm{M}$ (>2500-fold selective) for 79 of the kinases tested, with only $\mathrm{PKC} v$ (PKD3) demonstrating a sub-micromolar $\left(\mathrm{IC}_{50}=0.280 \mu \mathrm{M} ; 140\right.$ fold selective) $\mathrm{IC}_{50}$ value. 


\section{Structure of the TgCDPK1.33 Complex}

Previously, we demonstrated that certain substituents at the $\mathrm{R}_{2}$ position of the pyrazolopyrimidine scaffold enhance inhibitor potency and selectivity for $T g \mathrm{CDPK} 1 .^{25}$ While 1 has an $\mathrm{IC}_{50}$ of $2.9 \mathrm{nM}$ for $T g \mathrm{CDPK} 1$ and is $>3000$-fold selective for $T g \mathrm{CDPK} 1$ over the mammalian tyrosine kinase $\mathrm{Src}$, the $\mathrm{R}_{2}$ isopropyl analog of $\mathbf{1}$ has an $\mathrm{IC}_{50}$ of $5.0 \mathrm{nM}$ for $T g C D P K 1$ and is only 76 -fold selective for $T g C D P K 1$ over Src. ${ }^{19,25}$ The 2methylpropan-2-ol $\mathrm{R}_{2}$ group of inhibitors $\mathbf{3 2}$ and $\mathbf{3 3}$ seem to have a similar effect on selectivity as the $\mathrm{N}$-methyl-4-piperidinemethylene group of $\mathbf{1}$. For example, the $\mathrm{R}_{2}$ isopropyl analog of inhibitor $\mathbf{3 3}$ is only 40-fold selective for TgCDPK1 over Src, while 33, which contains a 2-methylpropan-2-ol $R_{2}$ group, is $>5000$-fold selective. To gain a better understanding of the contribution of the 2-methylpropan-2-ol $\mathrm{R}_{2}$ group to inhibitor binding, a co-crystal structure of $\mathbf{3 3}$ bound to $T g \mathrm{CDPK} 1$ in the calcium-free inactive form was determined (Figure 6). As expected, 33 occupies the ATP-binding cleft of $T g C D P K 1$, with the pyrazolopyrimidine scaffold making the same hydrophobic and hydrogen-bonding contacts as the adenine ring of ATP. In addition, the 2-cyclopropyloxyquinolin-6-yl $\mathrm{R}_{1}$ group of $\mathbf{3 3}$ is directed towards the Gly 128 gatekeeper residue of $T g \mathrm{CDPK} 1$, with the quinoline moiety occupying the enlarged hydrophobic pocket that is available due to the lack of a side chain at this position. Side chains of residues in helix-aC and the fourth $\beta$-strand of the $N$ terminal lobe form hydrophobic interactions with the 2-cyclopropyloxy group, most likely contributing to the favorable potencies of inhibitors containing this substituent. The $\mathrm{R}_{2}$ substituent of $\mathbf{3 3}$ occupies the ribose-binding pocket of $T g \mathrm{CDPK} 1$, with the tertiary alcohol of the $\mathrm{R}_{2}$ substituent directed towards the phosphate-binding loop (P-loop), which caps the ATP-binding site. Superposition of the $T g$ CDPK1.33 complex with the co-crystal structure of $T g$ CDPK1 bound to a close analog of $\mathbf{1}$ shows that the pyrazolopyrimidine scaffolds and $\mathrm{R}_{1}$ substituents of these inhibitors are well aligned within the ATP-binding site. However, the $\mathrm{R}_{2}$ groups of both inhibitors adopt very different orientations. While the 2methylpropan-2-ol $\mathrm{R}_{2}$ group of $\mathbf{3 3}$ is oriented towards the P-loop of $T g \mathrm{CDPK} 1$, the larger 4piperidinemethylene group of the $\mathbf{1}$ analog is directed out of the ATP-binding site (Figure 6C) and forms an electrostatic interaction with the side chain of Glu155, located on the surface of the $\mathrm{C}$-terminal lobe. Therefore, it appears that different interactions in the ribose pocket can be exploited by $\mathrm{R}_{2}$ substituents to confer high selectivity for $T g \mathrm{CDPK} 1$.

\section{Large Animal Pharmacokinetics}

The lack of toxicity in the initial mouse toxicity screens allowed us to move forward into large animal pharmacokinetic and tolerability profiling. Male calves ( $\mathrm{n}=2$ for each compound) were dosed orally at $10 \mathrm{mg} / \mathrm{kg}$ for compound $\mathbf{3 2}$ and $9.3 \mathrm{mg} / \mathrm{kg}$ for compound 33 and blood sampled up to 12 days after dosing (Figure 7). Similar to rats, the absorption of both compounds was slow with maximum concentrations reached at 24 hours for compound 33 and 12 hours for compound 32. The maximum plasma concentrations were similar for the two compounds, $7.9 \mu \mathrm{M}$ and $9.8 \mu \mathrm{M}$ for compound $\mathbf{3 2}$ and $\mathbf{3 3}$, respectively. However, the overall exposure to $\mathbf{3 3}$ was greater than that of $\mathbf{3 2}$ due to its lower oral clearance and longer half-life (Table 6). Yet, both compounds had very low oral clearances and long systemic half-lives. Similar to rats, compound $\mathbf{3 3}$ had a higher apparent volume of distribution than 
compound $\mathbf{3 2}$ and the overall distribution characteristics were similar to those observed in rats.

There were some notable calf health concerns following the single oral dose of compound 33. For compound 33, both calves developed neurologic signs of toxicity on day 4-5 postdose. Both calves were observed to have a plantigrade stance and ataxia. Despite abnormalities, both calves were ambulatory, alert, and responsive with normal appetites. The signs became progressively worse, with notable ataxia, followed by marked improvement by day 10 but were never completely resolved by the end of the experiment on day 14 . These signs were not observed for compound $\mathbf{3 2}$. One possibility for the increased CNS toxicity was the greater brain exposure for compound $\mathbf{3 3}$ compared with compound $\mathbf{3 2}$. The observed neurological signs of toxicity in compound $\mathbf{3 3}$ gave us reasons to no longer pursue further studies of this compound. Moving forward we chose to further characterize compound 32 before performing small animal efficacy studies and large animal PK studies.

\section{Further Toxicity Profiling of 32}

Potential further toxicity of compound $\mathbf{3 2}$ was examined in mice by testing two doses (30 $\mathrm{mg} / \mathrm{kg}$ and $100 \mathrm{mg} / \mathrm{kg}$ PO) daily for five days, while observing mice for signs of toxicity and collecting blood samples. Both groups of mice remained active, well-groomed, and appeared normal throughout the study. Upon necropsy, there were no gross abnormalities. Histology revealed mild focal inflammation in the spleen in two of three mice in the $30 \mathrm{mg} / \mathrm{kg}$ group. The only abnormality seen in the $100 \mathrm{mg} / \mathrm{kg}$ group was inflammatory infiltrate in the hepatic lobules in one of three mice. The concentrations following $30 \mathrm{mg} / \mathrm{kg}$ doses were slightly higher than those predicted from single dose PK data while the exposures following the 100 $\mathrm{mg} / \mathrm{kg}$ doses were similar to those predicted from single $10 \mathrm{mg} / \mathrm{kg}$ dose data (Figure 8). Similar to the early multiple dosing experiments in mice, after the last $100 \mathrm{mg} / \mathrm{kg}$ dose the elimination of compound $\mathbf{3 2}$ was slower than predicted with considerable plasma concentrations persisting at 72 hours after the final dose.

Next, we completed a maximally tolerated dose study to determine the lowest observable adverse effect level (LOAEL) and the no observable adverse effect level (NOAEL) of compound 32. Mice were dosed with single PO doses of $\mathbf{3 2}$ ranging from $200 \mathrm{mg} / \mathrm{kg}$ to 1000 $\mathrm{mg} / \mathrm{kg}$. The LOAEL was observed at $500 \mathrm{mg} / \mathrm{kg}$ and the NOAEL was observed at 400 $\mathrm{mg} / \mathrm{kg}$. Mice had slightly ruffled fur and were less active than the control mice at 3 hours following the $500 \mathrm{mg} / \mathrm{kg}$ dose. The lowered activity persisted at 24 hours but was resolved by 30 hours. The lack of toxicity up to $500 \mathrm{mg} / \mathrm{kg}$ confirmed the safety of the compound for small animal efficacy studies.

\section{Large Animal Pharmacokinetics of 32}

The pharmacokinetics of $\mathbf{3 2}$ was further explored in dogs and monkeys following IV and PO administration. Similar to rats, $\mathbf{3 2}$ had a very low clearance in both species and a relatively long half-life (Table 7). The plasma concentrations time-profile following IV dosing was biphasic in both species with a similar extent of distribution in dogs and monkeys as observed in rats and calves (Figure 9). The bioavailability of compound $\mathbf{3 2}$ was $66 \pm 17 \%$ in 
monkeys and $88 \pm 12 \%$ in dogs demonstrating good bioavailability in both species as predicted from rats.

\section{In Vivo Efficacy of 32 Against Acute and Latent T. gondii Infection in Mice}

We tested $\mathbf{3 2}$ against a high inoculum of type I RH strain $T$. gondii to determine efficacy against fulminate toxoplasmosis in two experiments (Figure 10). Unlike type II $T$. gondii strains, type I strains do not typically form tissue cysts but rather cause death within 10 days. Compound 32 was administered via oral gavage two days after infection and the burden of infection was measured 5 days after the initiation of treatment. Treatment with $\mathbf{3 2}$ at 20 $\mathrm{mg} / \mathrm{kg}$ for 5 days reduced the number of $T$. gondii tachyzoites in the peritoneal fluid below the limits of detection (less than 100 tachyzoites $/ \mathrm{mL}$ ). Treatment with $\mathbf{3 2}$ was highly effective at $20 \mathrm{mg} / \mathrm{kg}$ daily for 5 days in reducing infection in the spleen (more than 99\%), and infection in the brain (95\%). The efficacy of $\mathbf{3 2}$ against an acute $T$. gondii infection that is not adequately controlled by the mouse immune system suggests that $\mathbf{3 2}$ would be active against toxoplasmosis in an immunocompromised human.

We next tested $\mathbf{3 2}$ for its efficacy against latent murine toxoplasmosis by determining its ability to reduce $T$. gondii brain cysts (Fig. 11). ${ }^{34}$ Mice were infected IP with the type II ME49 strain of $T$. gondii, which recapitulates the non-lethal course of infection seen in humans, culminating in formation of cysts in the brain. Five weeks after infection, mice were treated once daily for 14 days via oral gavage with either $30 \mathrm{mg} / \mathrm{kg}$ of $\mathbf{3 2}$ or a vehicle control. An additional group of mice was dosed twice-days 1 and 7 -with $105 \mathrm{mg} / \mathrm{kg}$ of 32 . Mice were sacrificed and cyst numbers were determined from brain homogenate by microscopy two weeks after the last drug dose. The mean number of brain cysts for vehicletreated control mice was $1537 \pm 623$. Treatment with $30 \mathrm{mg} / \mathrm{kg}$ of 32 led to a reduction of brain cyst number of $88.7 \%$. The percent reduction in brain cyst number for the $105 \mathrm{mg} / \mathrm{kg}$ treated group was essentially the same (87.6\%). Importantly, no signs of toxicity or increased morbidity were observed in either drug-treated group. The favorable safety profile and brain permeability of $\mathbf{3 2}$ make it an attractive candidate to treat toxoplasmosis in pregnancy, as well as CNS toxoplasmosis, although we have not fully investigated it for effects on fetal development.

\section{Conclusions}

In the present study, we sought to identify PP-based inhibitors that possess all of the favorable properties of lead compound $\mathbf{1}$ but lack its hERG activity. To do this, analogs of $\mathbf{1}$, which contain variable $\mathrm{R}_{1}$ and $\mathrm{R}_{2}$ groups displayed from the PP-scaffold, were first screened for potent inhibition of the TgCDPK1 enzyme and $T$. gondii invasion/proliferation. Inhibitors of sufficient potency were then screened for the lack of growth inhibition of mammalian cell lines and minimal hERG activity. In this series of inhibitors, the key to eliminating hERG activity was replacing the $N$-methyl-4-piperidinemethylene $\mathrm{R}_{2}$ position group of $\mathbf{1}$ with a non-basic substituent that is able to confer a similar level of $T g$ CDPK1 selectivity. While a number of non-basic $\mathrm{R}_{2}$ substituents provided inhibitors with potent activity against $T$. gondii and minimal mammalian cell cytotoxicity and hERG activity, inhibitors $\mathbf{3 2}$ and 33, which contain a 2, 2-dimethylpropan-1-ol group at the $\mathrm{R}_{2}$ position, 
stood out due to their superior PK properties and adequate exposure to the CNS. However, the superior safety profile of inhibitor $\mathbf{3 2}$ coupled with its favorable pharmacokinetic characteristics in small and large animals made this compound the focus of antitoxoplasmosis efficacy studies. The efficacy of $\mathbf{3 2}$ in mouse models of acute and latent toxoplasmosis points to the promise of this drug for further development.

\section{EXPERIMENTAL PROCEDURES}

\section{General Synthetic Methods}

All chemicals were purchased from commercial suppliers and used without further purification unless otherwise stated. Reactions were monitored with thin-layer chromatography using silica gel 60 F254 coated glass plates (EM Sciences). Compound purification was performed with an IntelliFlash 280 automated flash chromatography system/Combi flash Rf+ using pre-packed Varian Super Flash/Redi sep Rf silica gel columns (hexanes/EtOAc or $\mathrm{CH}_{2} \mathrm{Cl}_{2} / \mathrm{MeOH}$ gradient solvent systems). A Varian Dynamax Microsorb 100-5 $\mathrm{C}_{18}$ column $(250 \mathrm{~mm} \times 21.4 \mathrm{~mm})$, eluting with $\mathrm{H}_{2} \mathrm{O} / \mathrm{CH}_{3} \mathrm{CN}$ and $\mathrm{H}_{2} \mathrm{O}$ / $\mathrm{MeOH}$ gradient solvent systems ( $+0.05 \%$ TFA) was used for preparatory HPLC purification. Products were detected by UV at $\lambda=254 \& 220 \mathrm{~nm}$. The purity of all final compounds was determined by two analytical RP-HPLC methods, using an Agilent ZORBAX SB-C ${ }_{18}(2.1$ $\mathrm{mm} \times 150 \mathrm{~mm}$ ) or Varian Microsorb-MV 100-5 $\mathrm{C}_{18}$ column $(4.6 \mathrm{~mm} \times 150 \mathrm{~mm})$, and eluting with either $\mathrm{H}_{2} \mathrm{O} / \mathrm{CH}_{3} \mathrm{CN}$ or $\mathrm{H}_{2} \mathrm{O} / \mathrm{MeOH}$ gradient solvent systems ( $+0.05 \%$ TFA) run over $30 \mathrm{~min}$. Products were detected by UV at $\lambda=254 \mathrm{~nm}$, with all final compounds displaying >95\% purity. NMR spectra were recorded on Bruker 300 or $500 \mathrm{MHz}$ spectrometers at ambient temperature. Chemical shifts are reported in parts per million $(\delta)$ and coupling constants in $\mathrm{Hz} .{ }^{1} \mathrm{H}-\mathrm{NMR}$ spectra were referenced to the residual solvent peaks as internal standards $\left(7.26 \mathrm{ppm}\right.$ for $\mathrm{CDCl}_{3}, 2.50 \mathrm{ppm}$ for $d_{6}$ DMSO, and $3.34 \mathrm{ppm}$ for $\mathrm{CD}_{3} \mathrm{OD}$ ). Mass spectra were recorded with a Bruker Esquire Liquid Chromatograph - Ion Trap Mass Spectrometer. The synthetic routes used to generate inhibitors are shown in Schemes 1-3.

Synthesis and purification methods for compounds 1-9 in Table 1 are described in previous publications. ${ }^{19,26}$ Protocols for synthesis of intermediates are provided in the Supporting Information.

General $\mathbf{R}_{\mathbf{2}}$ alkylation procedure-Pyrazolopyrimidine (1 equiv.), $\mathrm{K}_{2} \mathrm{CO}_{3}$ or $\mathrm{Cs}_{2} \mathrm{CO}_{3}$ or $\mathrm{K}_{2} \mathrm{CO}_{3}: \mathrm{NaH}_{2} \mathrm{PO}_{4}$ (1.5-2 equiv.), and an alkylhalide (1.1 equiv.) or alkylmesylate (1.1 equiv.) or oxirane (1.1 equiv.) were stirred in dry DMF at room temperature or $80{ }^{\circ} \mathrm{C}$. The reaction was monitored by thin layer chromatography. After completion, ethyl acetate and water were added and the organic phase was separated. The water phase was extracted with ethyl acetate. The combined organic phases were washed with brine, dried over $\mathrm{Na}_{2} \mathrm{SO}_{4}$ and evaporated under reduced pressure. The crude product was then purified via flash chromatography over silica, eluting with either a hexanes/EtOAc or $\mathrm{CH}_{2} \mathrm{Cl}_{2} / \mathrm{MeOH}$ gradient. If necessary, further purification was performed with preparatory RP-HPLC.

General Suzuki coupling procedure-3-Iodopyrazolopyrimidines or 3Bromopyrazolopyrimidines (1 equiv.), $\mathrm{Na}_{2} \mathrm{CO}_{3}$ or $\mathrm{K}_{3} \mathrm{PO}_{4}$ (2-4 equiv.), $\mathrm{Pd}\left(\mathrm{PPh}_{3}\right)_{4}$ or 
$\mathrm{Pd}(\mathrm{II}) \mathrm{Cl}_{2}$ dppf.DCM, (0.05 equiv.) and boronic acids or boronate pinacol esters (1-2 equiv.) were dissolved in a mixture of dimethoxyethane $(1.5 \mathrm{~mL})$ and water $(0.5 \mathrm{~mL})$ and then heated in a microwave at $80{ }^{\circ} \mathrm{C}$ for one hour. The reaction was monitored by thin layer chromatography. After cooling, ethyl acetate and water were added and the organic phase was separated. The water phase was extracted with ethyl acetate. The combined organic phases were washed with brine, dried over $\mathrm{Na}_{2} \mathrm{SO}_{4}$ and evaporated under reduced pressure. The crude product was then purified via flash chromatography over silica, eluting with either a hexanes/EtOAc or $\mathrm{CH}_{2} \mathrm{Cl}_{2} / \mathrm{MeOH}$ gradient. If necessary, further purification was performed with preparatory RP-HPLC.

General naphthol alkylation procedure-6-Hydroxy-2-naphthalene pyrazolopyrimidines (1 equiv.), $\mathrm{K}_{2} \mathrm{CO}_{3}$ or $\mathrm{Cs}_{2} \mathrm{CO}_{3}$ (1.5-2 equiv.), and alkyl halides/epoxides (1.1 equiv.), $\mathrm{NaH}_{2} \mathrm{PO}_{4}: \mathrm{K}_{2} \mathrm{CO}_{3}$ (1:1 equiv.), were stirred in dry DMF at room temperature or $60-80{ }^{\circ} \mathrm{C}$ and monitored by thin layer chromatography. After completion, ethyl acetate and water were added and the organic phase was separated. The water phase was extracted with ethyl acetate. The combined organic phases were washed with brine, dried over $\mathrm{Na}_{2} \mathrm{SO}_{4}$, and evaporated under reduced pressure. The crude product was then purified via flash chromatography over silica, eluting with either a hexanes/EtOAc or $\mathrm{CH}_{2} \mathrm{Cl}_{2} / \mathrm{MeOH}$ gradient. If necessary, further purification was performed with preparatory RP-HPLC.

General boc-deprotection procedure-Boc-amine-containing pyrazolopyrimidine was stirred in a TFA/ $\mathrm{CH}_{2} \mathrm{Cl}_{2}(1: 1)$ mixture for $\sim 3 \mathrm{~h}$. The reaction was then concentrated and purified via preparatory RP-HPLC. After HPLC purification, the product was then reconcentrated from $1.25 \mathrm{M} \mathrm{HCl}$ in EtOH to afford the final, purified product as a bis- $\mathrm{HCl}$ salt.

General reductive amination procedure-Deprotected pyrazolopyrimidines ( 1 equiv.) were dissolved in methanol and neutralized with sodium methoxide. A solution containing $2 \%$ acetic acid and an aldehyde or ketone (5-10 equiv.) was stirred at room temperature for $10 \mathrm{~min}$. Sodium cyanoborohydride (5 equiv.) was then added and the reaction was stirred until reaching completion, as determined by thin layer chromatography (typically $\sim 2 \mathrm{~h}$ ). The crude reaction was then purified via preparatory RP-HPLC. After HPLC purification, the residue was dissolved in a small amount of $2 \mathrm{M} \mathrm{HCl}$ in methanol and, after concentration in vacuo, the final product was obtained as an $\mathrm{HCl}$ salt.

3-(6-(Cyclopropylmethoxy)naphthalen-2-yl)-1-((1-methylpiperidin-4-yl)methyl)-1Hpyrazolo[3,4-d]pyrimidin-4-amine (10): Tert-butyl-4-((4-amino-3-(6hydroxynaphthalen-2-yl)-1 $H$-pyrazolo[3,4- $d$ ]pyrimidin-1-yl)methyl)piperidine-1carboxylate ${ }^{26}$ and (bromomethyl)cyclopropane were subjected to the General naphthol alkylation procedure followed by the General boc-deprotection procedure and General reductive amination procedure in order to afford 10. ${ }^{1} \mathrm{H} \mathrm{NMR}\left(300 \mathrm{MHz}, \mathrm{CD}_{3} \mathrm{OD}\right) \delta 8.51$ $(\mathrm{s}, 1 \mathrm{H}), 8.17(\mathrm{~s}, 1 \mathrm{H}), 8.01(\mathrm{~d}, J=8.5 \mathrm{~Hz}, 1 \mathrm{H}), 7.93(\mathrm{~d}, J=9.1 \mathrm{~Hz}, 1 \mathrm{H}), 7.81(\mathrm{~d}, J=9.3 \mathrm{~Hz}$, $1 \mathrm{H}), 7.36(\mathrm{~s}, 1 \mathrm{H}), 7.30(\mathrm{~d}, J=9.3 \mathrm{~Hz}, 1 \mathrm{H}), 4.56(\mathrm{~d}, J=6.4 \mathrm{~Hz}, 2 \mathrm{H}), 4.03(\mathrm{~d}, J=6.6 \mathrm{~Hz}, 2 \mathrm{H})$, $3.57(\mathrm{~m}, 2 \mathrm{H}), 3.06(\mathrm{~m}, 2 \mathrm{H}), 2.88(\mathrm{~s}, 3 \mathrm{H}), 2.45(\mathrm{~m}, 1 \mathrm{H}), 2.02(\mathrm{~m}, 2 \mathrm{H}), 1.77(\mathrm{~m}, 2 \mathrm{H}), 1.44(\mathrm{~m}$, $1 \mathrm{H}), 0.71(\mathrm{~m}, 2 \mathrm{H}), 0.46(\mathrm{~m}, 2 \mathrm{H})$; MS (ESI) $443.5 \mathrm{~m} / \mathrm{z}[\mathrm{MH}+], \mathrm{C}_{26} \mathrm{H}_{31} \mathrm{~N}_{6} \mathrm{O}$ requires 443.5. 
3-(6-Cyclobutoxynaphthalen-2-yl)-1-((1-methylpiperidin-4-yl)methyl)-1H-pyrazolo[3,4d]pyrimidin-4-amine (11): 2-(6-Cyclobutoxynaphthalen-2-yl)-4,4,5,5-tetramethyl-1,3,2dioxaborolane (38) and tert-butyl-4-((4-amino-3-iodo-1 H-pyrazolo[3,4- $d$ ] pyrimidin-1yl)methyl)piperidine-1-carboxylate ${ }^{19}$ were subjected to the General Suzuki coupling procedure followed by the General boc-deprotection procedure and General reductive amination procedure in order to afford 11. ${ }^{1} \mathrm{H} \mathrm{NMR}\left(300 \mathrm{MHz}, \mathrm{CD}_{3} \mathrm{OD}\right) \delta 8.47(\mathrm{~s}, 1 \mathrm{H})$, $8.15(\mathrm{~s}, 1 \mathrm{H}), 7.99(\mathrm{~d}, J=8.3 \mathrm{~Hz}, 1 \mathrm{H}), 7.92(\mathrm{~d}, J=9.5 \mathrm{~Hz}, 1 \mathrm{H}), 7.80(\mathrm{~d}, J=8.9 \mathrm{~Hz}, 1 \mathrm{H}), 7.24$ $(\mathrm{m}, 2 \mathrm{H}), 4.53(\mathrm{~d}, J=6.6 \mathrm{~Hz}, 2 \mathrm{H}), 3.56(\mathrm{~m}, 2 \mathrm{H}), 3.03(\mathrm{~m}, 2 \mathrm{H}), 2.86(\mathrm{~s}, 3 \mathrm{H}), 2.62(\mathrm{~m}, 2 \mathrm{H})$, $2.44(\mathrm{~m}, 1 \mathrm{H}), 2.22(\mathrm{~m}, 2 \mathrm{H}), 2.04-1.60(\mathrm{~m}, 6 \mathrm{H})$; MS (ESI) $443.4 \mathrm{~m} / z[\mathrm{MH}+], \mathrm{C}_{26} \mathrm{H}_{31} \mathrm{~N}_{6} \mathrm{O}$ requires 443.2 .

3-(6-Cyclopropoxynaphthalen-2-yl)-1-((1-methylpiperidin-4-yl)methyl)-1Hpyrazolo[3,4-d]pyrimidin-4-amine (12): 2-(6-Cyclopropoxynaphthalen-2-yl)-4,4,5,5tetramethyl-1,3,2- dioxaborolane (41) and tert-butyl-4-((4-amino-3-iodo-1 $H$-pyrazolo[3,4d]pyrimidin-1-yl)methyl)piperidine-1-carboxylate were subjected to the General Suzuki coupling procedure followed by the General boc-deprotection procedure and General reductive amination procedure in order to afford $12 .{ }^{1} \mathrm{H} \mathrm{NMR}\left(300 \mathrm{MHz}, \mathrm{CD}_{3} \mathrm{OD}\right) \delta 8.49$ (s, $1 \mathrm{H}), 8.17(\mathrm{~s}, 1 \mathrm{H}), 8.03(\mathrm{~d}, J=8.5 \mathrm{~Hz}, 1 \mathrm{H}), 7.92(\mathrm{~d}, J=9.1 \mathrm{~Hz}, 1 \mathrm{H}), 7.80(\mathrm{~d}, J=8.5 \mathrm{~Hz}$, $1 \mathrm{H}), 7.64(\mathrm{~d}, J=2.0 \mathrm{~Hz}, 1 \mathrm{H}), 7.27$ (dd, $J=8.9,1.8 \mathrm{~Hz}, 1 \mathrm{H}), 4.52(\mathrm{~d}, J=6.0 \mathrm{~Hz}, 2 \mathrm{H}), 3.98$ $(\mathrm{m}, 1 \mathrm{H}), 3.56(\mathrm{~m}, 2 \mathrm{H}), 3.05(\mathrm{~m}, 2 \mathrm{H}), 2.87(\mathrm{~s}, 3 \mathrm{H}), 2.44(\mathrm{~m}, 1 \mathrm{H}), 2.00(\mathrm{~m}, 2 \mathrm{H}), 1.76(\mathrm{~m}, 2 \mathrm{H})$, $0.92(\mathrm{~m}, 2 \mathrm{H}), 0.80(\mathrm{~m}, 2 \mathrm{H})$; MS (ESI) $429.5 \mathrm{~m} / z$ [MH+], $\mathrm{C}_{25} \mathrm{H}_{29} \mathrm{~N}_{6} \mathrm{O}$ requires 429.6.

3-(6-(2-Methoxyethoxy)naphthalen-2-yl)-1-((1-methylpiperidin-4-yl)methyl)-1Hpyrazolo[3,4-d]pyrimidin-4-amine (13): Tert-butyl-4-((4-amino-3-(6hydroxynaphthalen-2-yl)-1 $H$-pyrazolo[3,4- $d$ ]pyrimidin-1-yl)methyl)piperidine-1carboxylate ${ }^{26}$ and bromomethoxyethane were subjected to the General naphthol alkylation procedure followed by the General boc-deprotection procedure and General reductive amination procedure in order to afford $13 .{ }^{1} \mathrm{H}$ NMR $\left(300 \mathrm{MHz}, \mathrm{CD}_{3} \mathrm{OD}\right) \delta 8.50(\mathrm{~s}, 1 \mathrm{H})$, $8.16(\mathrm{~s}, 1 \mathrm{H}), 8.01(\mathrm{~d}, J=7.8 \mathrm{~Hz}, 1 \mathrm{H}), 7.93(\mathrm{~d}, J=8.5 \mathrm{~Hz}, 1 \mathrm{H}), 7.80(\mathrm{~d}, J=8.3 \mathrm{~Hz}, 1 \mathrm{H}), 7.40$ (s, $1 \mathrm{H}), 7.30(\mathrm{~d}, J=7.8 \mathrm{~Hz}, 1 \mathrm{H}), 4.52(\mathrm{~d}, J=4.2 \mathrm{~Hz}, 2 \mathrm{H}), 4.31(\mathrm{~m}, 2 \mathrm{H}), 3.86(\mathrm{~m}, 2 \mathrm{H}), 3.62$ (m, 2H), 3.54 (s, 3H), 3.04 (m, 2H), 2.87 (s, 3H), $2.44(\mathrm{~m}, 1 \mathrm{H}), 1.99(\mathrm{~m}, 2 \mathrm{H}), 1.77(\mathrm{~m}, 2 \mathrm{H})$; MS (ESI) $447.5 \mathrm{~m} / z[\mathrm{MH}+], \mathrm{C}_{25} \mathrm{H}_{31} \mathrm{~N}_{6} \mathrm{O}_{2}$ requires 447.5 .

1-((1-Methylpiperidin-4-yl)methyl)-3-(6-(oxetan-3-yloxy)naphthalen-2-yl)-1Hpyrazolo[3,4-d]pyrimidin-4-amine (14): Tert-butyl-4-((4-amino-3-(6hydroxynaphthalen-2-yl)-1 $H$-pyrazolo[3,4- $d$ ]pyrimidin-1-yl)methyl)piperidine-1carboxylate $^{19}$ and 3-bromooxetane were subjected to the General naphthol alkylation procedure followed by the General boc-deprotection procedure and General reductive amination procedure in order to afford 14. ${ }^{1} \mathrm{H}$ NMR $\left(300 \mathrm{MHz}, \mathrm{CD}_{3} \mathrm{OD}\right) \delta 8.49(\mathrm{~s}, 1 \mathrm{H})$, $8.18(\mathrm{~s}, 1 \mathrm{H}), 8.06-7.92(\mathrm{~m}, 2 \mathrm{H}), 7.82(\mathrm{~d}, J=8.5 \mathrm{~Hz}, 1 \mathrm{H}), 7.51(\mathrm{~s}, 1 \mathrm{H}), 7.36(\mathrm{~d}, J=9.1 \mathrm{~Hz}$, $1 \mathrm{H}), 4.81(\mathrm{~m}, 1 \mathrm{H}), 4.53(\mathrm{~d}, J=5.6 \mathrm{~Hz}, 2 \mathrm{H}), 3.99-3.84(\mathrm{~m}, 4 \mathrm{H}), 3.57(\mathrm{~m}, 2 \mathrm{H}), 3.05(\mathrm{~m}, 2 \mathrm{H})$, $2.86(\mathrm{~s}, 3 \mathrm{H}), 2.44(\mathrm{~m}, 1 \mathrm{H}), 2.00(\mathrm{~m}, 2 \mathrm{H}), 1.74(\mathrm{~m}, 2 \mathrm{H}) ; \mathrm{MS}(\mathrm{ESI}) 445.2 \mathrm{~m} / z[\mathrm{MH}+]$, $\mathrm{C}_{25} \mathrm{H}_{29} \mathrm{~N}_{6} \mathrm{O}_{2}$ requires 445.2. 
2-(6-(4-Amino-1-((1-methylpiperidin-4-yl)methyl)-1H-pyrazolo[3,4-d]pyrimidin-3yl)naphthalen-2-yloxy)ethanol (15): Tert-butyl-4-((4-amino-3-(6-hydroxynaphthalen-2yl)-1 $H$-pyrazolo[3,4- $d$ ]pyrimidin-1-yl)methyl)piperidine-1-carboxylate ${ }^{19}$ and oxirane were subjected to the General naphthol alkylation procedure followed by the General bocdeprotection procedure and General reductive amination procedure in order to afford 15. ${ }^{1} \mathrm{H}$ NMR (300 MHz, $\left.\mathrm{CD}_{3} \mathrm{OD}\right) \delta 8.50(\mathrm{~s}, 1 \mathrm{H}), 8.17(\mathrm{~s}, 1 \mathrm{H}), 8.02(\mathrm{~d}, J=8.3 \mathrm{~Hz}, 1 \mathrm{H}), 7.94$ $(\mathrm{d}, J=8.9 \mathrm{~Hz}, 1 \mathrm{H}), 7.80(\mathrm{~d}, J=8.9 \mathrm{~Hz}, 1 \mathrm{H}), 7.41(\mathrm{~d}, J=2.2 \mathrm{~Hz}, 1 \mathrm{H}), 7.34(\mathrm{dd}, J=8.7,2.0$ $\mathrm{Hz}, 1 \mathrm{H}), 4.53(\mathrm{~d}, J=6.4 \mathrm{~Hz}, 2 \mathrm{H}), 4.25(\mathrm{t}, J=4.5 \mathrm{~Hz}, 2 \mathrm{H}), 3.99(\mathrm{t}, J=4.5 \mathrm{~Hz}, 2 \mathrm{H}), 3.56(\mathrm{~m}$, 2H), $3.04(\mathrm{~m}, 2 \mathrm{H}), 2.86(\mathrm{~s}, 3 \mathrm{H}), 2.44(\mathrm{~m}, 1 \mathrm{H}), 2.00(\mathrm{~m}, 2 \mathrm{H}), 1.72(\mathrm{~m}, 2 \mathrm{H})$; MS (ESI) 433.3 $\mathrm{m} / z[\mathrm{MH}+], \mathrm{C}_{24} \mathrm{H}_{29} \mathrm{~N}_{6} \mathrm{O}_{2}$ requires 433.5.

1-(6-(4-Amino-1-((1-methylpiperidin-4-yl)methyl)-1H-pyrazolo[3,4-d]pyrimidin-3yl)naphthalen-2-yloxy)-2-methylpropan-2-ol (16): Tert-butyl-4-((4-amino-3-(6hydroxynaphthalen-2-yl)-1 $H$-pyrazolo[3,4- $d$ ]pyrimidin-1-yl)methyl)piperidine-1carboxylate $^{19}$ and 2,2-dimethyloxirane were subjected to the General naphthol alkylation procedure followed by the General boc-deprotection procedure and General reductive amination procedure in order to afford 16. ${ }^{1} \mathrm{H}$ NMR $\left(300 \mathrm{MHz}, \mathrm{CD}_{3} \mathrm{OD}\right) \delta 8.48(\mathrm{~s}, 1 \mathrm{H})$, $8.17(\mathrm{~s}, 1 \mathrm{H}), 8.02(\mathrm{~d}, J=8.9 \mathrm{~Hz}, 1 \mathrm{H}), 7.94(\mathrm{~d}, J=8.7 \mathrm{~Hz}, 1 \mathrm{H}), 7.79(\mathrm{~d}, J=8.5 \mathrm{~Hz}, 1 \mathrm{H})$, 7.43-7.32 (m, 2H), 4.53 (d, J=6.8 Hz, 2H), $3.98(\mathrm{~s}, 2 \mathrm{H}), 3.56(\mathrm{~m}, 2 \mathrm{H}), 3.04(\mathrm{~m}, 2 \mathrm{H}), 2.87$ (s, 3H), $2.44(\mathrm{~m}, 1 \mathrm{H}), 2.00(\mathrm{~m}, 2 \mathrm{H}), 1.77(\mathrm{~m}, 2 \mathrm{H}), 1.41$ (s, 6H); MS (ESI) $461.5 \mathrm{~m} / \mathrm{z}[\mathrm{MH}+]$, $\mathrm{C}_{26} \mathrm{H}_{33} \mathrm{~N}_{6} \mathrm{O}_{2}$ requires 461.5.

3-(2-Ethoxyquinolin-6-yl)-1-((1-methylpiperidin-4-yl)methyl)-1H-pyrazolo[3,4d]pyrimidin-4-amine (17): Tert-butyl-4-((4-amino-3-(2-ethoxyquinolin-6-yl)-1 $\mathrm{H}$ pyrazolo[3,4-d]pyrimidin-1-yl)methyl)piperidine-1-carboxylate ${ }^{26}$ was subjected to the General boc-deprotection procedure and General reductive amination procedure in order to afford 17. ${ }^{1} \mathrm{H}$ NMR $\left(300 \mathrm{MHz}, \mathrm{CD}_{3} \mathrm{OD}\right) \delta 8.29(\mathrm{~s}, 1 \mathrm{H}), 8.22(\mathrm{~d}, J=8.2 \mathrm{~Hz}, 1 \mathrm{H}), 8.12(\mathrm{~s}$, $1 \mathrm{H}), 7.98(\mathrm{~m}, 2 \mathrm{H}), 7.04(\mathrm{~d}, J=8.5 \mathrm{~Hz}, 1 \mathrm{H}), 4.55(\mathrm{q}, J=6.8 \mathrm{~Hz}, 2 \mathrm{H}), 4.38(\mathrm{~d}, J=4.3 \mathrm{~Hz}$, 2H), 2.95 (m, 2H), 2.30 (s, 3H), 2.99 (m, 2H), 1.67 (m, 2H), 1.48(m, 4H); MS (ESI) 418.3 $\mathrm{m} / \mathrm{z}[\mathrm{MH}+], \mathrm{C}_{23} \mathrm{H}_{28} \mathrm{~N}_{7} \mathrm{O}$ requires 418.5 .

1-((1-Methylpiperidin-4-yl)methyl)-3-(2-(2,2,2-trifluoroethoxy)quinolin-6-yl)-1Hpyrazolo[3,4-d]pyrimidin-4-amine (18): 2-(2,2,2-Trifluoroethoxy)quinolin-6-ylboronic acid (39) and tert-butyl-4-((4-amino-3-iodo-1 $H$-pyrazolo[3,4- $d$ ]pyrimidin-1yl)methyl)piperidine-1-carboxylate ${ }^{19}$ were subjected to the General Suzuki coupling procedure followed by the General boc-deprotection procedure and General reductive amination procedure in order to afford $18 .{ }^{1} \mathrm{H}$ NMR $\left(300 \mathrm{MHz}, \mathrm{CD}_{3} \mathrm{OD}\right) \delta 8.49(\mathrm{~s}, 1 \mathrm{H})$, $8.39(\mathrm{~d}, J=8.5 \mathrm{~Hz}, 1 \mathrm{H}), 8.24(\mathrm{~s}, 1 \mathrm{H}), 8.04(\mathrm{~s}, 2 \mathrm{H}), 7.18(\mathrm{~d}, J=7.0 \mathrm{~Hz}, 1 \mathrm{H}), 5.09(\mathrm{q}, J=8.7$ $\mathrm{Hz}, 2 \mathrm{H}), 4.52$ (s, 2H), $3.54(\mathrm{~m}, 2 \mathrm{H}), 3.04(\mathrm{~m}, 2 \mathrm{H}), 2.84(\mathrm{~s}, 3 \mathrm{H}), 2.45(\mathrm{~m}, 1 \mathrm{H}), 1.98(\mathrm{~m}, 2 \mathrm{H})$, $1.75(\mathrm{~m}, 2 \mathrm{H}) ; \mathrm{MS}$ (ESI) $472.2 \mathrm{~m} / \mathrm{z}[\mathrm{MH}+], \mathrm{C}_{23} \mathrm{H}_{25} \mathrm{~F}_{3} \mathrm{~N}_{7} \mathrm{O}$ requires 472.5 .

3-(2-Cyclopropoxyquinolin-6-yl)-1-((1-methylpiperidin-4-yl)methyl)-1H-pyrazolo[3,4d]pyrimidin-4-amine (19): 2-Cyclopropoxyquinolin-6-ylboronic acid (40) and tert-butyl-4((4-amino-3-iodo-1 $H$-pyrazolo[3,4- $d$ ] pyrimidin-1-yl)methyl)piperidine-1-carboxylate ${ }^{19}$ were subjected to the General Suzuki coupling procedure followed by the General boc- 
deprotection procedure and General reductive amination procedure in order to afford 19. ${ }^{1} \mathrm{H}$ NMR (300 MHz, $\left.\mathrm{CD}_{3} \mathrm{OD}\right) \delta 9.17(\mathrm{~s}, 1 \mathrm{H}), 8.75-8.33(\mathrm{~m}, 3 \mathrm{H}), 8.28-7.98(\mathrm{~m}, 2 \mathrm{H})$, $4.72(\mathrm{~m}, 1 \mathrm{H}), 4.54(\mathrm{~d}, J=6.0 \mathrm{~Hz}, 2 \mathrm{H}), 3.56(\mathrm{~m}, 2 \mathrm{H}), 3.10(\mathrm{~m}, 2 \mathrm{H}), 3.00(\mathrm{~s}, 3 \mathrm{H}), 2.48(\mathrm{~m}$, $1 \mathrm{H}), 2.00(\mathrm{~m}, 2 \mathrm{H}), 1.60(\mathrm{~m}, 2 \mathrm{H}), 1.20-1.10(\mathrm{~m}, 4 \mathrm{H})$; MS (ESI) $430.5 \mathrm{~m} / z$ [MH+], $\mathrm{C}_{24} \mathrm{H}_{28} \mathrm{~N}_{7} \mathrm{O}$ requires 430.6 .

3-(2-Cyclopropoxyquinolin-6-yl)-1-(3-(dimethylamino)-2,2-dimethylpropyl)-1Hpyrazolo[3,4-d]pyrimidin-4-amine (20): 2-Cyclopropoxyquinolin-6-ylboronic acid (40) and 1-(3-(dimethylamino)-2,2-dimethylpropyl)-3-iodo-1 $H$-pyrazolo[3,4- $d$ ]pyrimidin-4amine (42) were subjected to the General Suzuki coupling procedure to afford 20. ${ }^{1} \mathrm{H}$ NMR $\left(300 \mathrm{MHz}, \mathrm{CD}_{3} \mathrm{OD}\right) \delta 8.29(\mathrm{~s}, 1 \mathrm{H}), 8.22(\mathrm{~d}, J=8.9 \mathrm{~Hz}, 1 \mathrm{H}),, 8.11(\mathrm{~d}, J=1.6 \mathrm{~Hz}, 1 \mathrm{H}) 8.01$ (s, $1 \mathrm{H}), 8.00$ (dd, $J=8.5,1.5 \mathrm{~Hz}, 1 \mathrm{H}$ ), 7.07 (d, $J=8.9 \mathrm{~Hz}, 1 \mathrm{H}), 4.46(\mathrm{~m}, 1 \mathrm{H}), 4.36(\mathrm{~s}, 2 \mathrm{H})$, $2.46(\mathrm{~s}, 2 \mathrm{H}), 2.44$ (s, 6H), $1.03(\mathrm{~s}, 6 \mathrm{H}), 0.93-0.82(\mathrm{~m}, 4 \mathrm{H})$. MS (ESI) $432.6 \mathrm{~m} / \mathrm{z}[\mathrm{MH}+]$, $\mathrm{C}_{24} \mathrm{H}_{30} \mathrm{~N}_{7} \mathrm{O}$ requires 432.5 .

3-(6-Ethoxynaphthalen-2-yl)-1-isobutyl-1H-pyrazolo[3,4-d]pyrimidin-4-amine (21): 6Ethoxynaphthalen-2-ylboronic acid and 3-iodo-1-isobutyl-1 $H$-pyrazolo[3,4- $d$ ] pyrimidin-4amine ${ }^{26}$ were subjected to the General Suzuki coupling procedure in order to afford $21 .{ }^{1} \mathrm{H}$ NMR $\left(300 \mathrm{MHz}, \mathrm{CD}_{3} \mathrm{OD}\right) \delta 8.27(\mathrm{~s}, 1 \mathrm{H}), 8.09(\mathrm{~s}, 1 \mathrm{H}), 7.96(\mathrm{~d}, J=8.1 \mathrm{~Hz}, 1 \mathrm{H}), 7.89(\mathrm{~d}, J=$ $9.1 \mathrm{~Hz}, 1 \mathrm{H}), 7.75(\mathrm{dd}, J=8.2,2.0 \mathrm{~Hz}, 1 \mathrm{H}), 7.32(\mathrm{~s}, 1 \mathrm{H}), 7.22(\mathrm{dd}, J=9.1,2.4 \mathrm{~Hz}, 1 \mathrm{H})$, $4.28-4.17(\mathrm{~m}, 4 \mathrm{H}), 2.39(\mathrm{~m}, 1 \mathrm{H}), 1.48(\mathrm{t}, J=6.8 \mathrm{~Hz}, 3 \mathrm{H}), 0.96$ (d, $J=6.6 \mathrm{~Hz}, 6 \mathrm{H}) ; \mathrm{MS}$ (ESI) $362.4 \mathrm{~m} / \mathrm{z}[\mathrm{MH}+], \mathrm{C}_{21} \mathrm{H}_{24} \mathrm{~N}_{5} \mathrm{O}$ requires 362.2.

3-(6-Cyclopropoxynaphthalen-2-yl)-1-isobutyl-1H-pyrazolo[3,4-d]pyrimidin-4-amine (22): 6-(4-Amino-1-isobutyl-1 $H$-pyrazolo[3,4- $d$ ]pyrimidin-3-yl)naphthalen-2-ol (46) and bromocyclopropane were subjected to the General naphthol alkylation procedure in order to afford 22. ${ }^{1} \mathrm{H}$ NMR (300 MHz, $\left.\mathrm{CD}_{3} \mathrm{OD}\right) \delta 8.27(\mathrm{~s}, 1 \mathrm{H}), 8.10(\mathrm{~s}, 1 \mathrm{H}), 7.98(\mathrm{~d}, J=8.7 \mathrm{~Hz}$, $1 \mathrm{H}), 7.89(\mathrm{~d}, J=8.9 \mathrm{~Hz}, 1 \mathrm{H}), 7.76(\mathrm{dd}, J=8.5,1.6 \mathrm{~Hz}, 1 \mathrm{H}), 7.61(\mathrm{~d}, J=2.2 \mathrm{~Hz}, 1 \mathrm{H}), 7.25-$ $7.18(\mathrm{dd}, J=8.9,2.2 \mathrm{~Hz}, 1 \mathrm{H}), 4.24(\mathrm{~d}, J=7.25 \mathrm{~Hz}, 2 \mathrm{H}), 3.95(\mathrm{~m}, 1 \mathrm{H}), 2.38(\mathrm{~m}, 1 \mathrm{H}), 0.97$ (d, $J=6.6 \mathrm{~Hz}, 6 \mathrm{H}), 0.90(\mathrm{~m}, 2 \mathrm{H}), 0.79(\mathrm{~m}, 2 \mathrm{H}) ; \mathrm{MS}(\mathrm{ESI}) 374.2 \mathrm{~m} / z[\mathrm{MH}+], \mathrm{C}_{22} \mathrm{H}_{24} \mathrm{~N}_{5} \mathrm{O}$ requires 374.4 .

3-(2-Cyclopropoxyquinolin-6-yl)-1-isobutyl-1H-pyrazolo[3,4-d]pyrimidin-4-amine (23): 2-Cyclopropoxyquinolin-6-ylboronic acid (40) and 3-iodo-1-isobutyl-1 $H$-pyrazolo[3,4d]pyrimidin-4-amine ${ }^{26}$ were subjected to the General Suzuki coupling procedure in order to afford 23. ${ }^{1} \mathrm{H}$ NMR (300 MHz, $\left.\mathrm{CD}_{3} \mathrm{OD}\right) \delta 8.25(\mathrm{~s}, 1 \mathrm{H}), 8.23(\mathrm{~d}, J=8.9 \mathrm{~Hz}, 1 \mathrm{H}), 8.10(\mathrm{~s}$, $1 \mathrm{H}), 8.00-7.91(\mathrm{~m}, 2 \mathrm{H}), 7.02(\mathrm{~d}, J=8.7 \mathrm{~Hz}, 1 \mathrm{H}), 4.46(\mathrm{~s}, 1 \mathrm{H}), 4.22$ (d, $J=7.4 \mathrm{~Hz}, 2 \mathrm{H}), 2.36$ (m, 1H), $0.96(\mathrm{~d}, J=6.6 \mathrm{~Hz}, 6 \mathrm{H}), 0.91-0.72(\mathrm{~m}, 4 \mathrm{H})$; MS (ESI) $375.4 \mathrm{~m} / z$ [MH+], $\mathrm{C}_{21} \mathrm{H}_{23} \mathrm{~N}_{6} \mathrm{O}$ requires 375.4.

3-(6-Cyclopropoxynaphthalen-2-yl)-1-((3-methyloxetan-3-yl)methyl)-1H-pyrazolo[3,4d]pyrimidin-4-amine (24): 2-(6-Cyclopropoxynaphthalen-2-yl)-4,4,5,5-tetramethyl-1,3,2dioxaborolane (41) and 3-iodo-1-((3-methyloxetan-3-yl)methyl)-1 $H$-pyrazolo[3,4-

d]pyrimidin-4-amine (44) were subjected to the General Suzuki coupling procedure in order to afford 24. ${ }^{1} \mathrm{H}$ NMR (300 MHz, $\left.\mathrm{CDCl}_{3}\right) \delta 8.39$ (s, 1H), 8.08 (s, 1H), 7.93 (d, $J=8.7$ 
$\mathrm{Hz}, 1 \mathrm{H}), 7.83(\mathrm{~d}, J=8.9 \mathrm{~Hz}, 1 \mathrm{H}), 7.77(\mathrm{~d}, J=9.4 \mathrm{~Hz}, 1 \mathrm{H}), 7.52(\mathrm{~s}, 1 \mathrm{H}), 7.24$ (dd, $J=10.0$, $3.0 \mathrm{~Hz}, 1 \mathrm{H}), 5.68(\mathrm{~s}, 2 \mathrm{H}), 4.90(\mathrm{~d}, J=6.1 \mathrm{~Hz}, 2 \mathrm{H}), 4.64(\mathrm{~s}, 2 \mathrm{H}), 4.45(\mathrm{~d}, J=6.1 \mathrm{~Hz}, 2 \mathrm{H})$, $3.91(\mathrm{~m}, 1 \mathrm{H}), 1.36(3,3 \mathrm{H}), 0.96-0.83(\mathrm{~m}, 4 \mathrm{H})$; MS (ESI) $402.2 \mathrm{~m} / z[\mathrm{MH}+], \mathrm{C}_{23} \mathrm{H}_{24} \mathrm{~N}_{5} \mathrm{O}_{2}$ requires 402.4 .

3-(2-Cyclopropoxyquinolin-6-yl)-1-((3-methyloxetan-3-yl)methyl)-1H-pyrazolo[3,4d]pyrimidin-4-amine (25): 2-Cyclopropoxyquinolin-6-ylboronic acid (40) and 3-iodo-1((3-methyloxetan-3-yl)methyl)-1 H-pyrazolo[3,4- $d$ ]pyrimidin-4-amine (44) were subjected to the General Suzuki coupling procedure in order to afford $25 .{ }^{1} \mathrm{H} \mathrm{NMR}\left(300 \mathrm{MHz}, \mathrm{CDCl}_{3}\right)$ $\delta 8.41(\mathrm{~s}, 1 \mathrm{H}), 8.12-8.01(\mathrm{~m}, 3 \mathrm{H}), 7.96(\mathrm{~d}, J=8.3 \mathrm{~Hz}, 1 \mathrm{H}), 6.97(\mathrm{~d}, J=8.0 \mathrm{~Hz}, 1 \mathrm{H}), 5.54(\mathrm{~s}$, $2 \mathrm{H}), 4.91(\mathrm{~d}, J=6.1 \mathrm{~Hz}, 2 \mathrm{H}), 4.64(\mathrm{~s}, 2 \mathrm{H}), 4.56(\mathrm{~m}, 1 \mathrm{H}), 4.45(\mathrm{~d}, J=6.1 \mathrm{~Hz}, 2 \mathrm{H}), 1.36(\mathrm{~s}$, $3 \mathrm{H}), 0.95-0.82(\mathrm{~m}, 4 \mathrm{H})$; MS (ESI) $403.2 \mathrm{~m} / \mathrm{z}[\mathrm{MH}+], \mathrm{C}_{22} \mathrm{H}_{23} \mathrm{~N}_{6} \mathrm{O}_{2}$ requires 403.4 .

3-(6-Cyclopropoxynaphthalen-2-yl)-1-((tetrahydro-2H-pyran-4-yl)methyl)-1Hpyrazolo[3,4-d]pyrimidin-4-amine (28): 2-(6-Cyclopropoxynaphthalen-2-yl)-4,4,5,5tetramethyl-1,3,2-dioxaborolane (41) and 3-iodo-1-((tetrahydro- $2 H$-pyran-4-yl)methyl)- $1 H$ pyrazolo[3,4-d]pyrimidin-4-amine ${ }^{26}$ were subjected to the General Suzuki coupling procedure in order to afford $28 .{ }^{1} \mathrm{H}$ NMR $\left(300 \mathrm{MHz}, \mathrm{CD}_{3} \mathrm{OD}\right) \delta 8.47(\mathrm{~s}, 1 \mathrm{H}), 8.16(\mathrm{~s}, 1 \mathrm{H})$, $8.03(\mathrm{~d}, J=8.2 \mathrm{~Hz}, 1 \mathrm{H}), 7.92(\mathrm{~d}, J=9.1 \mathrm{~Hz}, 1 \mathrm{H}), 7.78(\mathrm{~d}, J=8.2 \mathrm{~Hz}, 1 \mathrm{H}), 7.64(\mathrm{~s}, 1 \mathrm{H}), 7.27$ (dd, $J=9.1,2.2 \mathrm{~Hz}, 1 \mathrm{H}) 4.45(\mathrm{~d}, J=6.8 \mathrm{~Hz}, 2 \mathrm{H}),, 3.99(\mathrm{~m}, 1 \mathrm{H}), 3.76(\mathrm{~m}, 2 \mathrm{H}), 3.05(\mathrm{~m}, 2 \mathrm{H})$, $2.40(\mathrm{~m}, 1 \mathrm{H}), 1.61(\mathrm{~m}, 2 \mathrm{H}), 1.46(\mathrm{~m}, 2 \mathrm{H}), 0.93-0.80(\mathrm{~m}, 4 \mathrm{H})$; MS (ESI) $416.4 \mathrm{~m} / \mathrm{z}[\mathrm{MH}+]$, $\mathrm{C}_{24} \mathrm{H}_{25} \mathrm{~N}_{5} \mathrm{O}_{2}$ requires 416.4 .

\section{3-(2-Cyclopropoxyquinolin-6-yl)-1-((tetrahydro-2H-pyran-4-yl)methyl)-1H-}

pyrazolo[3,4-d]pyrimidin-4-amine (29): 2-Cyclopropoxyquinolin-6-ylboronic acid (40) and 3-iodo-1-((tetrahydro-2H-pyran-4-yl)methyl)- $1 H$-pyrazolo[3,4- $d$ ]pyrimidin-4-amine ${ }^{26}$ were subjected to the General Suzuki coupling procedure in order to afford 29. ${ }^{1} \mathrm{H}$ NMR $\left(300 \mathrm{MHz}, \mathrm{CD}_{3} \mathrm{OD}\right) \delta 8.31(\mathrm{~s}, 1 \mathrm{H}), 8.22(\mathrm{~d}, J=8.9 \mathrm{~Hz}, 1 \mathrm{H}), 8.12(\mathrm{~d}, J=1.8 \mathrm{~Hz}, 1 \mathrm{H}), 8.06$ $(\mathrm{d}, J=8.7 \mathrm{~Hz}, 1 \mathrm{H}), 8.00(\mathrm{dd}, J=8.5,1.2 \mathrm{~Hz}, 1 \mathrm{H}), 7.07(\mathrm{~d}, J=8.9 \mathrm{~Hz}, 1 \mathrm{H}), 4.47(\mathrm{~m}, 1 \mathrm{H})$ $4.36(\mathrm{~d}, J=7.2 \mathrm{~Hz}, 2 \mathrm{H}),, 3.98(\mathrm{~m}, 2 \mathrm{H}), 3.42(\mathrm{~m}, 2 \mathrm{H}), 2.34(\mathrm{~m}, 1 \mathrm{H}), 1.59(\mathrm{~m}, 2 \mathrm{H}), 1.49(\mathrm{~m}$, $2 \mathrm{H}), 0.93-0.83(\mathrm{~m}, 4 \mathrm{H})$; MS (ESI) $416.4 \mathrm{~m} / \mathrm{z}[\mathrm{MH}+], \mathrm{C}_{23} \mathrm{H}_{24} \mathrm{~N}_{6} \mathrm{O}_{2}$ requires 416.4 .

\section{1-(4-Amino-3-(6-ethoxynaphthalen-2-yl)-1H-pyrazolo[3,4-d]pyrimidin-1-yl)-2-}

methylpropan-2-ol (30): 6-Ethoxynaphthalen-2-ylboronic acid (41) and 1-(4-amino-3iodo-1 $H$-pyrazolo[3,4-d]pyrimidin-1-yl)-2-methylpropan-2-ol (43) were subjected to the General Suzuki coupling procedure to afford compound 30; ${ }^{1} \mathrm{H}$ NMR (300 $\left.\mathrm{MHz}, \mathrm{CD}_{3} \mathrm{OD}\right)$ $\delta 8.26(\mathrm{~s}, 1 \mathrm{H}), 8.09(\mathrm{~s}, 1 \mathrm{H}), 7.97-7.83(\mathrm{~m}, 2 \mathrm{H}), 7.76(\mathrm{dd}, J=8.2,1.4 \mathrm{~Hz}, 1 \mathrm{H}), 7.30(\mathrm{~d}, J=$ $2.0 \mathrm{~Hz}, 1 \mathrm{H}), 7.20(\mathrm{dd}, J=8.9,1.4 \mathrm{~Hz}, 1 \mathrm{H}), 4.41(\mathrm{~s}, 2 \mathrm{H}), 4.19(\mathrm{q}, J=7.0 \mathrm{~Hz}, 2 \mathrm{H}), 1.47$ (t, $J=$ $6.8 \mathrm{~Hz}, 3 \mathrm{H}), 1.28(\mathrm{~s}, 6 \mathrm{H})$. MS (ESI) $378.2 \mathrm{~m} / \mathrm{z}[\mathrm{MH}+], \mathrm{C}_{21} \mathrm{H}_{24} \mathrm{~N}_{5} \mathrm{O}_{2}$ requires 378.1.

1-(4-Amino-3-(2-ethoxyquinolin-6-yl)-1H-pyrazolo[3,4-d]pyrimidin-1-yl)-2methylpropan-2-ol (31): 2-Ethoxy-6-(4,4,5,5-tetramethyl-1,3,2-dioxaborolan-2yl)quinoline ${ }^{19}$ and 1-(4-amino-3-iodo-1 $H$-pyrazolo[3,4- $d$ ]pyrimidin-1-yl)-2methylpropan-2-ol (43) were subjected to the General Suzuki coupling procedure to afford compound 31; ${ }^{1} \mathrm{H}$ NMR $\left(300 \mathrm{MHz}, \mathrm{CD}_{3} \mathrm{OD}\right) \delta 8.69(\mathrm{~d}, J=9.1 \mathrm{~Hz}, 1 \mathrm{H}), 8.45(\mathrm{~s}, 1 \mathrm{H}), 8.34$ 
(s, 1H), $8.17(\mathrm{~d}, J=8.0 \mathrm{~Hz}, 1 \mathrm{H}), 8.04(\mathrm{~d}, J=7.4 \mathrm{~Hz}, 1 \mathrm{H}), 7.45(\mathrm{~d}, J=7.4 \mathrm{~Hz}, 1 \mathrm{H}), 4.67$ (q, $J$ $=6.0 \mathrm{~Hz}, 2 \mathrm{H}), 4.50(\mathrm{~s}, 2 \mathrm{H}), 1.54(\mathrm{t}, J=6.5 \mathrm{~Hz}, 3 \mathrm{H}), 1.31(\mathrm{~s}, 6 \mathrm{H}) . \mathrm{MS}(\mathrm{ESI}) 379.2 \mathrm{~m} / z[\mathrm{MH}$ $+], \mathrm{C}_{20} \mathrm{H}_{23} \mathrm{~N}_{6} \mathrm{O}_{2}$ requires 379.1 .

1-(4-Amino-3-(6-cyclopropoxynaphthalen-2-yl)-1H-pyrazolo[3,4-d]pyrimidin-1-yl)-2methylpropan-2-ol (32): 2-(6-Cyclopropoxynaphthalen-2-yl)-4,4,5,5-tetramethyl-1,3,2dioxaborolane (41) and 1-(4-amino-3-iodo-1 $H$-pyrazolo[3,4- $d$ ]pyrimidin-1-yl)-2methylpropan-2-ol (43) were subjected to the General Suzuki coupling procedure to afford title compound 32; ${ }^{1} \mathrm{H}$ NMR $\left(500 \mathrm{MHz}, \mathrm{CD}_{3} \mathrm{OD}\right) \delta 8.26(\mathrm{~s}, 1 \mathrm{H}), 8.08(\mathrm{~s}, 1 \mathrm{H}), 7.93(\mathrm{~d}, J=$ $8.4 \mathrm{~Hz}, 1 \mathrm{H}), 7.85$ (d, $J=8.81 \mathrm{~Hz}, 1 \mathrm{H}), 7.76(\mathrm{~d}, J=8.4 \mathrm{~Hz}, 1 \mathrm{H}), 7.57$ (s, 1H), 7.20 (dd, $J=$ $8.8,1.8 \mathrm{~Hz}, 1 \mathrm{H}), 4.40(\mathrm{~s}, 2 \mathrm{H}), 3.91(\mathrm{~m}, 1 \mathrm{H}), 1.27(\mathrm{~s}, 6 \mathrm{H}), 0.88(\mathrm{~m}, 2 \mathrm{H}), 0.78(\mathrm{~m}, 2 \mathrm{H}) . \mathrm{MS}$ (ESI) $390.2 \mathrm{~m} / \mathrm{z}[\mathrm{MH}+], \mathrm{C}_{22} \mathrm{H}_{24} \mathrm{~N}_{5} \mathrm{O}_{2}$ requires 390.1 .

1-(4-Amino-3-(2-cyclopropoxyquinolin-6-yl)-1H-pyrazolo[3,4-d]pyrimidin-1-yl)-2methylpropan-2-ol (33): 2-Cyclopropoxyquinolin-6-ylboronic acid (40) and 1-(4-amino-3iodo-1 $H$-pyrazolo[3,4- $d$ ]pyrimidin-1-yl)-2-methylpropan-2-ol (43) were subjected to the General Suzuki coupling procedure in order to afford 33. NMR ( $\left.300 \mathrm{MHz}, \mathrm{CD}_{3} \mathrm{OD}\right) \delta 8.28$ (s, $1 \mathrm{H}), 8.28-8.24$ (d, $J=8.9 \mathrm{~Hz}, 1 \mathrm{H}), 8.15(\mathrm{t}, J=1.4 \mathrm{~Hz}, 1 \mathrm{H}), 8.01(\mathrm{~d}, J=1.2 \mathrm{~Hz}, 2 \mathrm{H}), 7.06$ (d, $J=8.7 \mathrm{~Hz}, 1 \mathrm{H}), 4.53-4.45(\mathrm{~m}, 1 \mathrm{H}), 4.42(\mathrm{~s}, 2 \mathrm{H}), 1.28(\mathrm{~s}, 6 \mathrm{H}), 0.92-0.85(\mathrm{~m}, 2 \mathrm{H}), 0.85-$ $0.77\left(\mathrm{~m}, 2 \mathrm{H}\right.$ ); MS (ESI) $391.1 \mathrm{~m} / z\left[\mathrm{MH}^{+}\right], \mathrm{C}_{21} \mathrm{H}_{23} \mathrm{~N}_{6} \mathrm{O}_{2}$ requires 391.2 .

3-(4-Amino-3-(6-cyclopropoxynaphthalen-2-yl)-1H-pyrazolo[3,4-d]pyrimidin-1-yl)-2,2dimethylpropan-1-ol (34): 2-(6-Cyclopropoxynaphthalen-2-yl)-4,4,5,5-tetramethyl-1,3,2dioxaborolane (41) and previously reported 3-(4-amino-3-iodo- $1 H$-pyrazolo[3,4d]pyrimidin-1-yl)-2,2-dimethylpropan-1-ol ${ }^{26}$ were subjected to the General Suzuki coupling procedure in order to afford $34 .{ }^{1} \mathrm{H}$ NMR $\left(300 \mathrm{MHz}, \mathrm{CD}_{3} \mathrm{OD}\right) \delta 8.30(\mathrm{~s}, 1 \mathrm{H}), 8.12$ (s, $1 \mathrm{H}), 8.00(\mathrm{~d}, J=8.7 \mathrm{~Hz}, 1 \mathrm{H}), 7.90(\mathrm{~d}, J=8.9 \mathrm{~Hz}, 1 \mathrm{H}), 7.78(\mathrm{dd}, J=8.2,1.5 \mathrm{~Hz}, 1 \mathrm{H})$, $7.62(\mathrm{~d}, J=2.4,1 \mathrm{H}), 7.24$ (dd, $J=9.1,2.4 \mathrm{~Hz}, 1 \mathrm{H}), 4.33(\mathrm{~s}, 2 \mathrm{H}), 3.97(\mathrm{~m}, 1 \mathrm{H}), 3.32(\mathrm{~s}, 2 \mathrm{H})$, $1.22(\mathrm{~s}, 6 \mathrm{H}), 0.94-0.81(\mathrm{~m}, 4 \mathrm{H})$; MS (ESI) $404.5 \mathrm{~m} / z[\mathrm{MH}+], \mathrm{C}_{23} \mathrm{H}_{26} \mathrm{~N}_{5} \mathrm{O}_{2}$ requires 404.4 .

3-(4-Amino-3-(2-cyclopropoxyquinolin-6-yl)-1H-pyrazolo[3,4-d]pyrimidin-1-yl)-2,2dimethylpropan-1-ol (35): 2-Cyclopropoxyquinolin-6-ylboronic acid (40) and previously reported 3-(4-amino-3-iodo-1 H-pyrazolo[3,4- $d$ ]pyrimidin-1-yl)-2,2-dimethylpropan-1-ol ${ }^{26}$ were subjected to the General Suzuki coupling procedure in order to afford 35 . ${ }^{1} \mathrm{H}$ NMR $\left(300 \mathrm{MHz}, \mathrm{CD}_{3} \mathrm{OD}\right) \delta 8.65(\mathrm{~s}, 1 \mathrm{H}), 8.50(\mathrm{~s}, 1 \mathrm{H}), 8.36(\mathrm{~m}, 1 \mathrm{H}), 8.21-8.05(\mathrm{~m}, 2 \mathrm{H}), 7.51(\mathrm{~d}, J$ $=8.3 \mathrm{~Hz}, 1 \mathrm{H}), 4.59(\mathrm{~s}, 2 \mathrm{H}), 4.47(\mathrm{~s}, 2 \mathrm{H}), 4.46(\mathrm{~m}, 1 \mathrm{H}), 1.01(\mathrm{~s}, 6 \mathrm{H}), 0.70(\mathrm{~m}, 4 \mathrm{H}) ; \mathrm{MS}(\mathrm{ESI})$ $405.2 \mathrm{~m} / \mathrm{z}[\mathrm{MH}+], \mathrm{C}_{22} \mathrm{H}_{25} \mathrm{~N}_{6} \mathrm{O}_{2}$ requires 405.4 .

3-(4-Amino-3-(2-(2,2,2-trifluoroethoxy)quinolin-6-yl)-1H-pyrazolo[3,4-d]pyrimidin-1yl)-2,2-dimethylpropan-1-ol (36): 2-(2,2,2-Trifluoroethoxy)quinolin-6-ylboronic acid (39) and previously reported 3-(4-amino-3-iodo- $1 H$-pyrazolo[3,4- $d$ ]pyrimidin-1-yl)-2,2dimethylpropan-1-ol ${ }^{26}$ were subjected to the General Suzuki coupling procedure in order to afford 36. ${ }^{1} \mathrm{H}$ NMR $\left(300 \mathrm{MHz}, \mathrm{CD}_{3} \mathrm{OD}\right) \delta 8.40(\mathrm{~s}, 1 \mathrm{H}), 8.17(\mathrm{~d}, J=8.7 \mathrm{~Hz}, 1 \mathrm{H}), 8.07(\mathrm{~d}, J=$ $1.6 \mathrm{~Hz}, 1 \mathrm{H}), 8.01-7.95(\mathrm{~m}, 2 \mathrm{H}), 7.12(\mathrm{~d}, J=8.9 \mathrm{~Hz}, 1 \mathrm{H}), 4.98(\mathrm{q}, J=8.5 \mathrm{~Hz}, 2 \mathrm{H}), 4.35$ (s, $2 \mathrm{H}), 3.15(\mathrm{~s}, 2 \mathrm{H}), 1.05(\mathrm{~s}, 6 \mathrm{H})$; MS (ESI) $447.5 \mathrm{~m} / \mathrm{z}[\mathrm{MH}+], \mathrm{C}_{21} \mathrm{H}_{21} \mathrm{~F}_{3} \mathrm{~N}_{6} \mathrm{O}_{2}$ requires 447.4 . 
2-((4-Amino-3-(6-cyclopropoxynaphthalen-2-yl)-1H-pyrazolo[3,4-d]pyrimidin-1yl)methyl)-1,1,1,3,3,3-hexafluoropropan-2-ol (37): 2-(6-Cyclopropoxynaphthalen-2yl)-4,4,5,5-tetramethyl-1,3,2-dioxaborolane (41) and 2-((4-amino-3-iodo- $1 H$-pyrazolo[3,4d]pyrimidin-1-yl)methyl)-1,1,1,3,3,3-hexafluoropropan-2-ol (45) were subjected to the General Suzuki coupling procedure in order to afford 37. ${ }^{1} \mathrm{H}$ NMR $\left(300 \mathrm{MHz}, \mathrm{CD}_{3} \mathrm{OD}\right) \delta$ $8.32(\mathrm{~s}, 1 \mathrm{H}), 8.11(\mathrm{~s}, 1 \mathrm{H}), 7.97(\mathrm{~d}, J=8.5 \mathrm{~Hz}, 1 \mathrm{H}), 7.87(\mathrm{~d}, J=9.1 \mathrm{~Hz}, 1 \mathrm{H}), 7.76(\mathrm{dd}, J=$ $8.5,1.6 \mathrm{~Hz}, 1 \mathrm{H}), 7.59(\mathrm{~d}, J=2.0,1 \mathrm{H}), 7.23(\mathrm{dd}, J=8.9,2.2 \mathrm{~Hz}, 1 \mathrm{H}), 5.03(\mathrm{~s}, 2 \mathrm{H}), 3.94(\mathrm{~m}$, $1 \mathrm{H}), 0.94-0.76(\mathrm{~m}, 4 \mathrm{H})$; MS (ESI) $498.2 \mathrm{~m} / \mathrm{z}[\mathrm{MH}+], \mathrm{C}_{22} \mathrm{H}_{18} \mathrm{~F}_{6} \mathrm{~N}_{5} \mathrm{O}_{2}$ requires 498.2.

\section{Physiochemical Procedures}

Pharmacokinetic analysis in mice-For mouse oral PK studies, three female BALB/c mice (10 to 12 weeks old) were used in each group (performed under IACUC protocol number 2145-01 (UW, Seattle)). Each group received a test compound at a dose of $10 \mathrm{mg} / \mathrm{kg}$ body weight dissolved in 3\% ethanol/7\% Tween $80 / 90 \%$ normal saline by oral gavage. Blood samples were taken at the designated time points by tail bleeding and centrifuged to obtain plasma. The samples were frozen at $-20{ }^{\circ} \mathrm{C}$. The test compounds were extracted from the plasma samples using acetonitrile $/ 0.1 \%$ formic acid with an internal standard. A standard mix of all test compounds was prepared for comparison and quantification. The compounds were quantified by LC/MS analysis. PK calculations were performed using Phoenix WinNonlin software (Pharsight).

Pharmacokinetic analysis in rats-Test compound was administered to SpragueDawley jugular canulated rats (Charles River) by either oral gavage or IV injection followed by blood sampling from the jugular vein at designated time points (performed under IACUC protocol number 2145-01 (UW, Seattle)). The oral dose was administered to each rat at 20 $\mathrm{mg} / \mathrm{kg}$ for compound $\mathbf{3 2}$ and $5 \mathrm{mg} / \mathrm{kg}$ for compound $\mathbf{3 3}$ at time $=0$ in a $1 \mathrm{~mL}$ volume of dosing solution (7\% Tween 80, 3\% EtOH, 5\% DMSO, 0.9\% saline.) IV injections were administered at $5 \mathrm{mg} / \mathrm{kg}$ from time $=0$ to 3 minutes in a $1 \mathrm{~mL}$ volume of dosing solution, and blood was sampled at the same time points via the jugular vein. Experiments were performed with groups of 2 rats each for the oral and IV dosing. Plasma was separated and extracted with acetonitrile and quantified by LC/MS analysis. PK calculations were performed using Phoenix WinNonlin software (Pharsight).

Pharmacokinetic analysis in calves-Previously described procedures were used for calf enrollment, housing, management, and for test compound administration (performed under WSU IACUC \# ASAF 04477 "Novel Therapeutics for Cryptosporidiosis and other Parasites: Bumped Kinase Inhibitors"). ${ }^{36}$

Pharmacokinetic analysis in dogs and monkeys-In each study, groups of three animals received a $1 \mathrm{mg} / \mathrm{kg}$ intravenous or oral dose of compound 32. The dose was administered as a solution in PEG-400 containing $10 \%$ DMSO ( $0.5 \mathrm{ml} / \mathrm{kg}$ dose volume); the oral dose solution was placed in a capsule just prior to dosing. Blood samples for plasma concentration analysis were obtained from each animal for 24 hours after dosing. Plasma concentrations of parent drug were determined by LC-MS/MS. All studies involving 
vertebrate animals at AbbVie were approved by an animal ethics approval committee (IACUC).

Distribution of compounds between mouse plasma and brain-Mice were injected with 32 or $33(5 \mathrm{mg} / \mathrm{kg}$ IP) and sacrificed at the indicated times for collection of plasma and brain (performed under IACUC protocol number 2145-01 (UW, Seattle)). Compound was dissolved in $0.4 \mathrm{~mL}$ of dosing solution (7\% Tween $80,3 \%$ ethanol, $5 \%$ DMSO, $0.9 \%$ saline) for IP injections. The brains were weighed and immediately frozen, then later homogenized in acetonitrile. Prior to animal studies, recovery of test compound was carried out by adding a known amount to a mouse brain in the test extraction solvent and performing the homogenization. Compound recovery was determined by liquid chromatography/tandem mass spectrometry analysis relative to a standard compound amount. Blood was taken from the same mice in heparinized capillary tubes for determination of compound concentration in plasma. The concentration of compound in the brain was obtained by dividing the moles of compound in the brain by the brain volume (obtained from the brain weight assuming $1 \mathrm{~g}$ is $1 \mathrm{~mL}$ ) and correcting for the brain vasculature volume of $3 \%$ by weight.

\section{Supplementary Material}

Refer to Web version on PubMed Central for supplementary material.

\section{Acknowledgments}

Funding Sources

We thank DeAnne Stolarik (Abbvie) and Lance Heinle (Abbvie) for assistance with the dog and monkey PK studies. Research reported in this publication was supported by the National Institute of General Medical Sciences, National Institute of Allergy and Infectious Diseases and National Institute of Child Health and Human Development of the National Institutes of Health under award numbers R01GM086858, R01AI089441, R01AI111341, and R01HD080670. The content is solely the responsibility of the authors and does not necessarily represent the official views of the National Institutes of Health. This work was also supported in part by Award \# 2014-06183 from the United States Department of Agriculture, by Career Development Award \# BX002440 from the United States Department of Veterans Affairs Biomedical Laboratory Research and Development, and by Award 07R1857 from the Stanley Medical Research Institute. Crystallography performed in support of the work benefitted from remote access to resources at the Stanford Synchrotron Radiation Lightsource supported by the U.S. Department of Energy Office of Basic Energy Sciences under Contract No. DE-AC02-76SF00515 and by the National Institutes of Health (P41GM103393).

\section{ABBREVIATIONS USED}

AUC area under plasma concentration time curve

ATP adenosine triphosphate

Boc tert-butyloxycarbonyl

CDPK1 calcium-dependent protein kinase 1

CL clearance

Cmax maximum plasma concentration 


$\begin{array}{ll}\text { CNS } & \text { central nervous system } \\ \text { DIAD } & \text { diisopropyl azodicarboxylate } \\ \text { DMF } & \text { dimethylformamide } \\ \text { dppf } & 1,1^{\prime} \text {-bis(diphenylphosphino)ferrocene } \\ \text { EC }_{\mathbf{5 0}} & \text { half maximal effective concentration } \\ \text { GI }_{50} & \text { half maximal growth inhibition } \\ \text { hERG } & \text { human Ether-à-go-go-Related Gene } \\ \text { IC } & \text { half maximal inhibitory concentration } \\ \text { IV } & \text { intravenous } \\ \text { K } & \text { Michaelis constant } \\ \text { PO } & \text { per os } \\ \text { tmax } & \text { time at which maximum concentration is reached } \\ \text { TBDMS } & \text { tert-butyldimethylsilyl } \\ \text { TgCDPK1 } & \text { Toxoplasma gondii CDPK1 }\end{array}$

\section{References}

1. Tenter AM, Heckeroth AR, Weiss LM. Toxoplasma gondii: from animals to humans. Int J Parasitol. 2000; 30:1217-1258. [PubMed: 11113252]

2. Pappas G, Roussos N, Falagas ME. Toxoplasmosis snapshots: global status of Toxoplasma gondii seroprevalence and implications for pregnancy and congenital toxoplasmosis. Int J Parasitol. 2009; 39:1385-1394. [PubMed: 19433092]

3. Schwartzman, JD.; Maguire, JH. In Tropical Infectious Diseases: Principles, Pathogens and Practice. 3rd. W. B. Saunders; Edinburgh, U.K.: 2011. Toxoplasmosis; p. 722-728.Chapter 103

4. Dupont CD, Christian DA, Hunter CA. Immune response and immunopathology during toxoplasmosis. Semin Immunopathol. 2012; 34:793-813. [PubMed: 22955326]

5. Blanchard N, Dunay IR, Schluter D. Persistence of Toxoplasma gondii in the central nervous system: a fine-tuned balance between the parasite, the brain and the immune system. Parasite Immunol. 2015; 37:150-158. [PubMed: 25573476]

6. Flegr J, Prandota J, Sovickova M, Israili ZH. Toxoplasmosis-a global threat. Correlation of latent toxoplasmosis with specific disease burden in a set of 88 countries. PLoS One. 2014; 9:e90203. [PubMed: 24662942]

7. Jones JL, Muccioli C, Belfort R Jr, Holland GN, Roberts JM, Silveira C. Recently acquired Toxoplasma gondii infection, Brazil. Emerging Infect Dis. 2006; 12:582-587. [PubMed: 16704805]

8. Carlier Y, Truyens C, Deloron P, Peyron F. Congenital parasitic infections: a review. Acta Trop. 2012; 121:55-70. [PubMed: 22085916]

9. Dubey JP, Jones JL. Toxoplasma gondii infection in humans and animals in the United States. Int J Parasitol. 2008; 38:1257-1278. [PubMed: 18508057]

10. Wei HX, Wei SS, Lindsay DS, Peng HJ. A Systematic Review and Meta-Analysis of the Efficacy of Anti-Toxoplasma gondii Medicines in Humans. PLoS One. 2015; 10:e0138204. [PubMed: 26394212] 
11. Kaplan JE, Benson C, Holmes KK, Brooks JT, Pau A, Masur H, Centers for Disease Control and Prevention (CDC); NIH Publ. HIV Medicine Asso. of the Infect. Dis. Soc. of America Guidelines for prevention and treatment of opportunistic infections in HIV-infected adults and adolescents: recommendations from CDC, the National Institutes of Health, and the HIV Medicine Association of the Infectious Diseases Society of America. MMWR. 2009; 58:1-207.

12. Kieschnick H, Wakefield T, Narducci CA, Beckers C. Toxoplasma gondii attachment to host cells is regulated by a calmodulin-like domain protein kinase. J Biol Chem. 2001; 276:12369-12377. [PubMed: 11154702]

13. Lourido S, Shuman J, Zhang C, Shokat KM, Hui R, Sibley LD. Calcium-dependent protein kinase 1 is an essential regulator of exocytosis in Toxoplasma. Nature. 2010; 465:359-362. [PubMed: 20485436]

14. Lourido S, Zhang C, Lopez MS, Tang K, Barks J, Wang Q, Wildman SA, Shokat KM, Sibley LD. Optimizing small molecule inhibitors of calcium-dependent protein kinase 1 to prevent infection by Toxoplasma gondii. J Med Chem. 2013; 56:3068-3077. [PubMed: 23470217]

15. Doggett JS, Ojo KK, Fan E, Maly DJ, Van Voorhis WC. Bumped kinase inhibitor 1294 treats established Toxoplasma gondii infection. Antimicrob Agents Chemother. 2014; 58:3547-3549. [PubMed: 24687502]

16. Zhang Z, Ojo KK, Johnson SM, Larson ET, He P, Geiger JA, Castellanos-Gonzalez A, White AC Jr, Parsons M, Merritt EA, Maly DJ, Verlinde CL, Van Voorhis WC, Fan E.

Benzoylbenzimidazole-based selective inhibitors targeting Cryptosporidium parvum and Toxoplasma gondii calcium-dependent protein kinase-1. Bioorg Med Chem Lett. 2012; 22:52645267. [PubMed: 22795629]

17. Zhang Z, Ojo KK, Vidadala R, Huang W, Geiger JA, Scheele S, Choi R, Reid MC, Keyloun KR, Rivas K, Siddaramaiah LK, Comess KM, Robinson KP, Merta PJ, Kifle L, Hol WG, Parsons M, Merritt EA, Maly DJ, Verlinde CL, Van Voorhis WC, Fan E. Potent and selective inhibitors of CDPK1 from $T$. gondii and $C$. parvum Based on a 5-aminopyrazole-4-carboxamide scaffold. ACS Med Chem Lett. 2014; 5:40-44. [PubMed: 24494061]

18. Murphy RC, Ojo KK, Larson ET, Castellanos-Gonzalez A, Perera BG, Keyloun KR, Kim JE, Bhandari JG, Muller NR, Verlinde CL, White AC Jr, Merritt EA, Van Voorhis WC, Maly DJ. Discovery of Potent and Selective Inhibitors of Calcium-Dependent Protein Kinase 1 (CDPK1) from C. parvum and T. gondii. ACS Med Chem Lett. 2010; 1:331-335. [PubMed: 21116453]

19. Johnson SM, Murphy RC, Geiger JA, DeRocher AE, Zhang Z, Ojo KK, Larson ET, Perera BG, Dale EJ, He P, Reid MC, Fox AM, Mueller NR, Merritt EA, Fan E, Parsons M, Van Voorhis WC, Maly DJ. Development of Toxoplasma gondii calcium-dependent protein kinase 1 (TgCDPK1) inhibitors with potent anti-toxoplasma activity. J Med Chem. 2012; 55:2416-2426. [PubMed: 22320388]

20. Ojo KK, Larson ET, Keyloun KR, Castaneda LJ, Derocher AE, Inampudi KK, Kim JE, Arakaki TL, Murphy RC, Zhang L, Napuli AJ, Maly DJ, Verlinde CL, Buckner FS, Parsons M, Hol WG, Merritt EA, Van Voorhis WC. Toxoplasma gondii calcium-dependent protein kinase 1 is a target for selective kinase inhibitors. Nat Struct Mol Biol. 2010; 17:602-607. [PubMed: 20436472]

21. Ojo KK, Reid MC, Kallur Siddaramaiah L, Muller J, Winzer P, Zhang Z, Keyloun KR, Vidadala RS, Merritt EA, Hol WG, Maly DJ, Fan E, Van Voorhis WC, Hemphill A. Neospora caninum calcium-dependent protein kinase 1 is an effective drug target for neosporosis therapy. PLoS One. 2014; 9:e92929. [PubMed: 24681759]

22. Winzer P, Muller J, Aguado-Martinez A, Rahman M, Balmer V, Manser V, Ortega-Mora LM, Ojo KK, Fan E, Maly DJ, Van Voorhis WC, Hemphill A. In Vitro and In Vivo Effects of the Bumped Kinase Inhibitor 1294 in the Related Cyst-Forming Apicomplexans Toxoplasma gondii and Neospora caninum. Antimicrob Agents Chemother. 2015; 59:6361-6374. [PubMed: 26248379]

23. Ojo KK, Eastman RT, Vidadala R, Zhang Z, Rivas KL, Choi R, Lutz JD, Reid MC, Fox AM, Hulverson MA, Kennedy M, Isoherranen N, Kim LM, Comess KM, Kempf DJ, Verlinde CL, Su XZ, Kappe SH, Maly DJ, Fan E, Van Voorhis WC. A specific inhibitor of PfCDPK4 blocks malaria transmission: chemical-genetic validation. J Infect Dis. 2014; 209:275-284. [PubMed: 24123773]

24. van Noord C, Eijgelsheim M, Stricker BH. Drug- and non-drug-associated QT interval prolongation. Br J Clin Pharmacol. 2010; 70:16-23. [PubMed: 20642543] 
25. Larson ET, Ojo KK, Murphy RC, Johnson SM, Zhang Z, Kim JE, Leibly DJ, Fox AM, Reid MC, Dale EJ, Perera BG, Kim J, Hewitt SN, Hol WG, Verlinde CL, Fan E, Van Voorhis WC, Maly DJ, Merritt EA. Multiple determinants for selective inhibition of apicomplexan calcium-dependent protein kinase CDPK1. J Med Chem. 2012; 55:2803-2810. [PubMed: 22369268]

26. Vidadala RS, Ojo KK, Johnson SM, Zhang Z, Leonard SE, Mitra A, Choi R, Reid MC, Keyloun KR, Fox AM, Kennedy M, Silver-Brace T, Hume JC, Kappe S, Verlinde CL, Fan E, Merritt EA, Van Voorhis WC, Maly DJ. Development of potent and selective Plasmodium falciparum calciumdependent protein kinase 4 ( $P f C D P K 4)$ inhibitors that block the transmission of malaria to mosquitoes. Eur J Med Chem. 2014; 74:562-573. [PubMed: 24531197]

27. Hanke JH, Gardner JP, Dow RL, Changelian PS, Brissette WH, Weringer EJ, Pollok BA, Connelly PA. Discovery of a novel, potent, and Src family-selective tyrosine kinase inhibitor. Study of Lckand FynT-dependent T cell activation. J biol chem. 1996; 271:695-701. [PubMed: 8557675]

28. Bridal TR, Margulis M, Wang X, Donio M, Sorota S. Comparison of human Ether-a-go-go related gene screening assays based on IonWorks Quattro and thallium flux. Assay Drug Dev Technol. 2010; 8:755-765. [PubMed: 20658944]

29. Bowes J, Brown AJ, Hamon J, Jarolimek W, Sridhar A, Waldron G, Whitebread S. Reducing safety-related drug attrition: the use of in vitro pharmacological profiling. Nat Rev Drug Discov. 2012; 11:909-22. [PubMed: 23197038]

30. Hitchcock SA, Pennington LD. Structure-brain exposure relationships. J Med Chem. 2006; 49:7559-7583. [PubMed: 17181137]

31. Cheng Y, Brown J, Judd TC, Lopez P, Qian W, Powers TS, Chen JJ, Bartberger MD, Chen K, Dunn RT, Epstein O, Fremeau RT Jr, Harried S, Hickman D, Hitchcock SA, Luo Y, Minatti AE, Patel VF, Vargas HM, Wahl RC, Weiss MM, Wen PH, White RD, Whittington DA, Zheng XM, Wood S. An Orally Available BACE1 Inhibitor That Affords Robust CNS A $\beta$ Reduction without Cardiovascular Liabilities. ACS Med Chem Lett. 2015; 6:210-215. [PubMed: 25699151]

32. Epstein O, Bryan MC, Cheng AC, Derakhchan K, Dineen TA, Hickman D, Hua Z, Human JB, Kreiman C, Marx IE, Weiss MM, Wahl RC, Wen PH, Whittington DA, Wood S, Zheng XM, Fremeau RT Jr, White RD, Patel VF. Lead optimization and modulation of hERG activity in a series of aminooxazoline xanthene $\beta$-site amyloid precursor protein cleaving enzyme (BACE1) inhibitors. J Med Chem. 2014; 57:9796-9810. [PubMed: 25389560]

33. Keyloun KR, Reid MC, Choi R, Song Y, Fox AM, Hillesland HK, Zhang Z, Vidadala R, Merritt EA, Lau AO, Maly DJ, Fan E, Barrett LK, WC VANV, Ojo KK. The gatekeeper residue and beyond: homologous calcium-dependent protein kinases as drug development targets for veterinarian Apicomplexa parasites. Parasitology. 2014; 141:1499-1509. [PubMed: 24927073]

34. Doggett JS, Nilsen A, Forquer I, Wegmann KW, Jones-Brando L, Yolken RH, Bordón C, Charman SA, Katneni K, Schultz T, Burrows JN, Hinrichs DJ, Meunier B, Carruthers VB, Riscoe MK. Endochin-like quinolones are highly efficacious against acute and latent experimental toxoplasmosis. Proc Natl Acad Sci USA. 2012; 109:15936-15941. [PubMed: 23019377]

35. Edvinsson B, Lappalainen M, Evengård B, ESCMID Study Group for Toxoplasmosis. Real-time PCR targeting a 529-bp repeat element for diagnosis of toxoplasmosis. Clin Microbiol Infect. 2006; 12:131-136. [PubMed: 16441450]

36. Ollivett TL, Nydam DV, Bowman DD, Zambriski JA, Bellosa ML, Linden TC, Divers TJ. Effect of nitazoxanide on cryptosporidiosis in experimentally infected neonatal dairy calves. J Dairy Sci. 2009; 92:1643-1648. [PubMed: 19307646] 
A
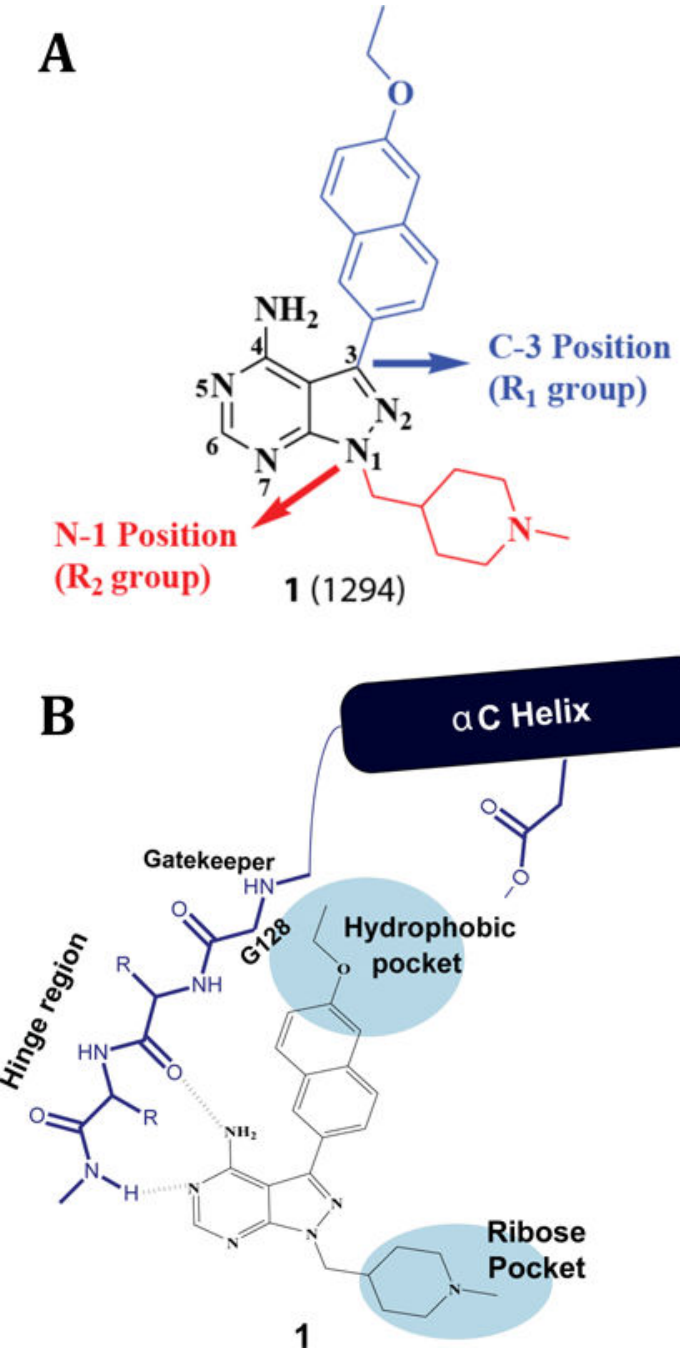

Figure 1.

Inhibitor 1. (A) The chemical structure of compound 1. Pyrazolopyrimidine scaffold numbering and sites of inhibitor derivatization $\left(\mathrm{R}_{1}\right.$ and $\left.\mathrm{R}_{2}\right)$ are shown. (B) Schematic of how 1 interacts with the ATP-binding site of $T g C D P K 1$. 


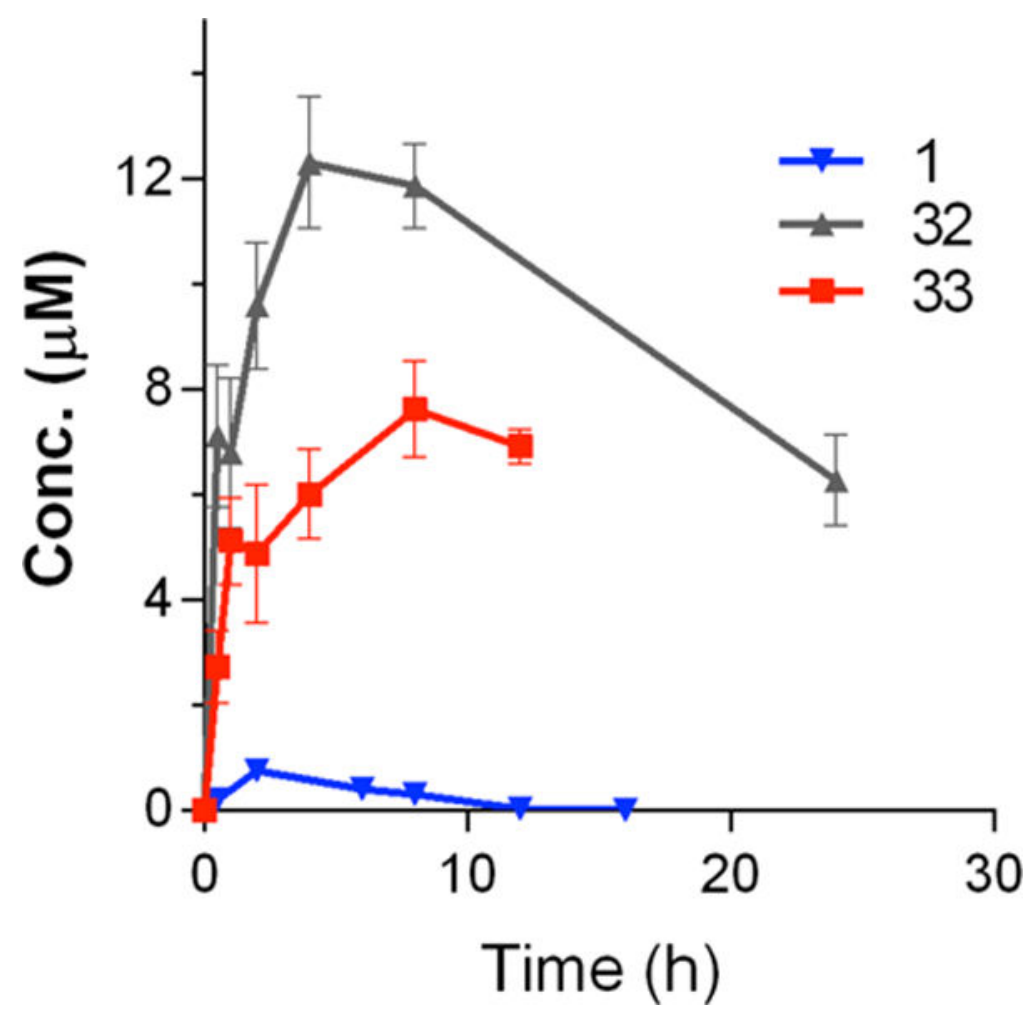

Figure 2.

Comparison of oral PK for compounds $\mathbf{3 2}$ and $\mathbf{3 3}$ in mice. Both compounds were dosed at $10 \mathrm{mg} / \mathrm{kg}$, PO. 

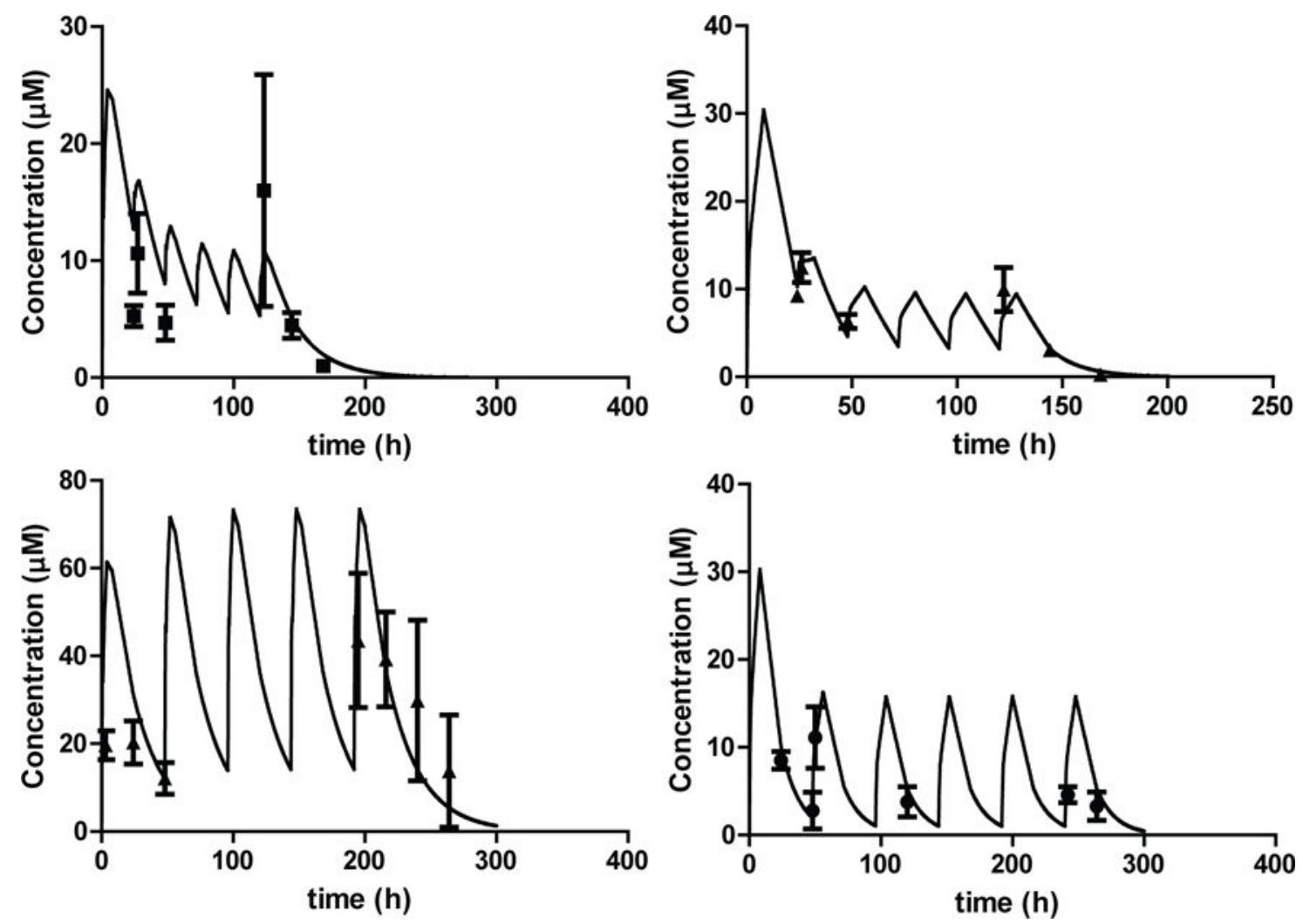

Figure 3.

Multiple dose PK studies with compound 32 and 33. The dosing regimens were simulated based on the disposition data following single oral doses to mice (lines) and the observed plasma concentrations (dots) compared to the simulation. (top left panel) 32 was dosed at 20 $\mathrm{mg} / \mathrm{kg}$ on day 1 and then $5 \mathrm{mg} / \mathrm{kg}$ every 24 hours for 5 doses. (bottom left panel) 32 was dosed at $50 \mathrm{mg} / \mathrm{kg}$ every 48 hours for 5 doses. (top right panel) 33 was dosed at $20 \mathrm{mg} / \mathrm{kg}$ on day 1 and then $5 \mathrm{mg} / \mathrm{kg}$ every 24 hours for 5 doses. (bottom right panel) 33 was dosed at 20 $\mathrm{mg} / \mathrm{kg}$ on day 1 and then $10 \mathrm{mg} / \mathrm{kg}$ every 48 hours for 5 doses. Each dot is a mean of 3 mice with standard deviation. 

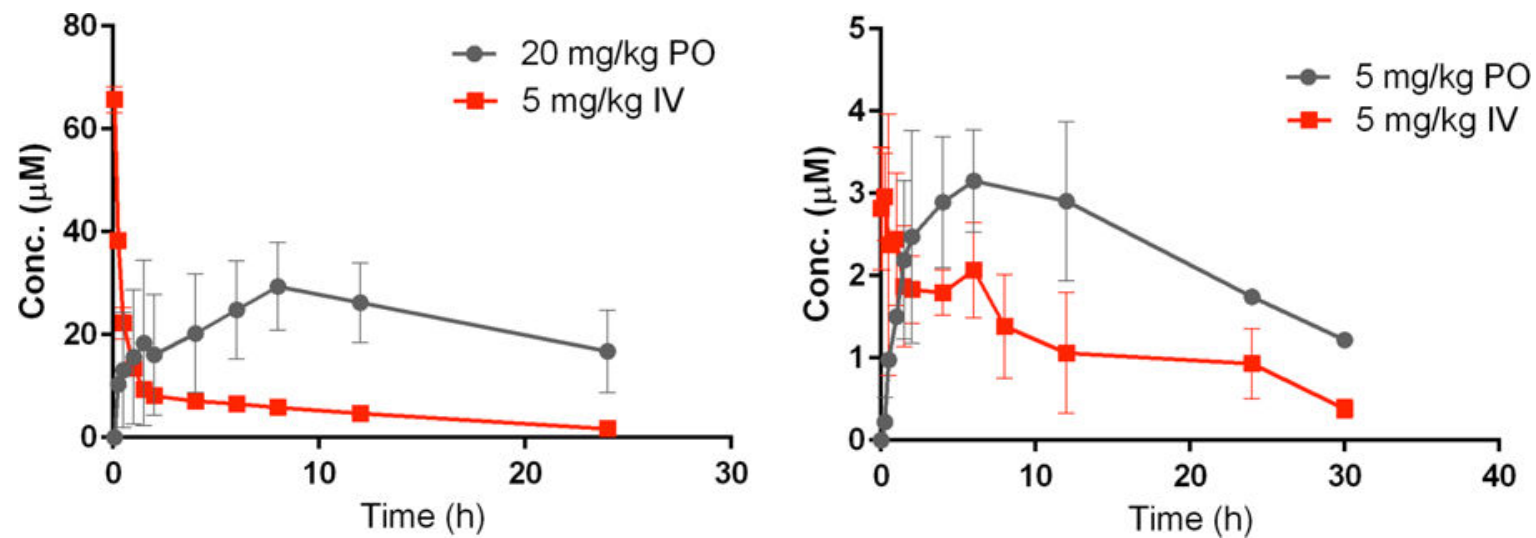

Figure 4.

Plasma concentration time curves for compound $\mathbf{3 2}$ (left) and $\mathbf{3 3}$ (right) following IV and $\mathrm{PO}$ dosing to rats. 


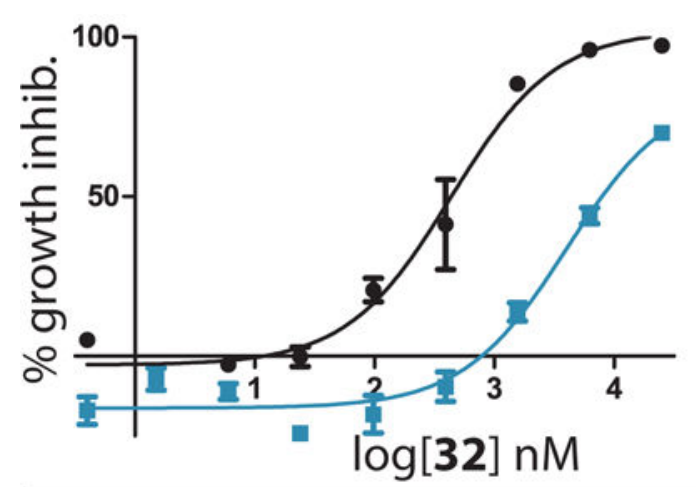

$=$ wt TgCDPK1 $\left(\mathrm{EC}_{50}=0.43 \mu \mathrm{M}\right)$ $=\mathrm{G} 128 \mathrm{M}$ TgCDPK1 $\left(\mathrm{EC}_{50}=4.0 \mu \mathrm{M}\right)$

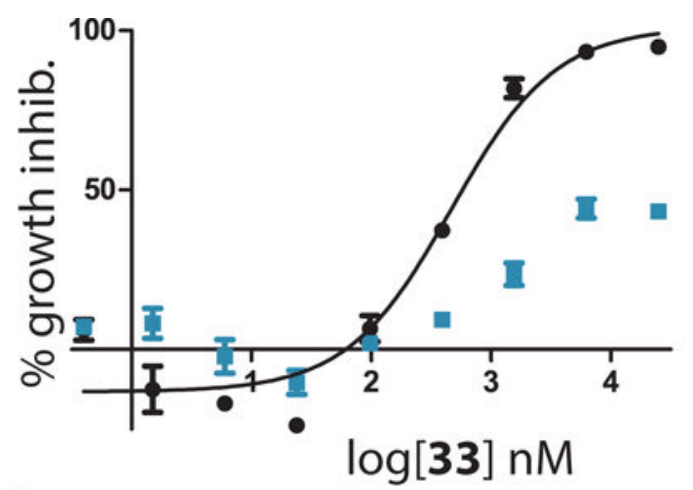

0 = wt TgCDPK1 $\left(\mathrm{EC}_{50}=0.47 \mu \mathrm{M}\right)$ $\square=\mathrm{G} 128 \mathrm{M}$ TgCDPK1 $\left(\mathrm{EC}_{50}=>25 \mu \mathrm{M}\right)$

Figure 5.

$\mathrm{EC}_{50}$ curves of inhibitors $\mathbf{3 2}$ (left) and $\mathbf{3 3}$ (right) for $T$. gondii over-expressing either wild type (wt) $T g C D P K 1$ (black circles) or a drug resistant G128M TgCDPK1 mutant (blue squares). All experiments were performed in triplicate. 

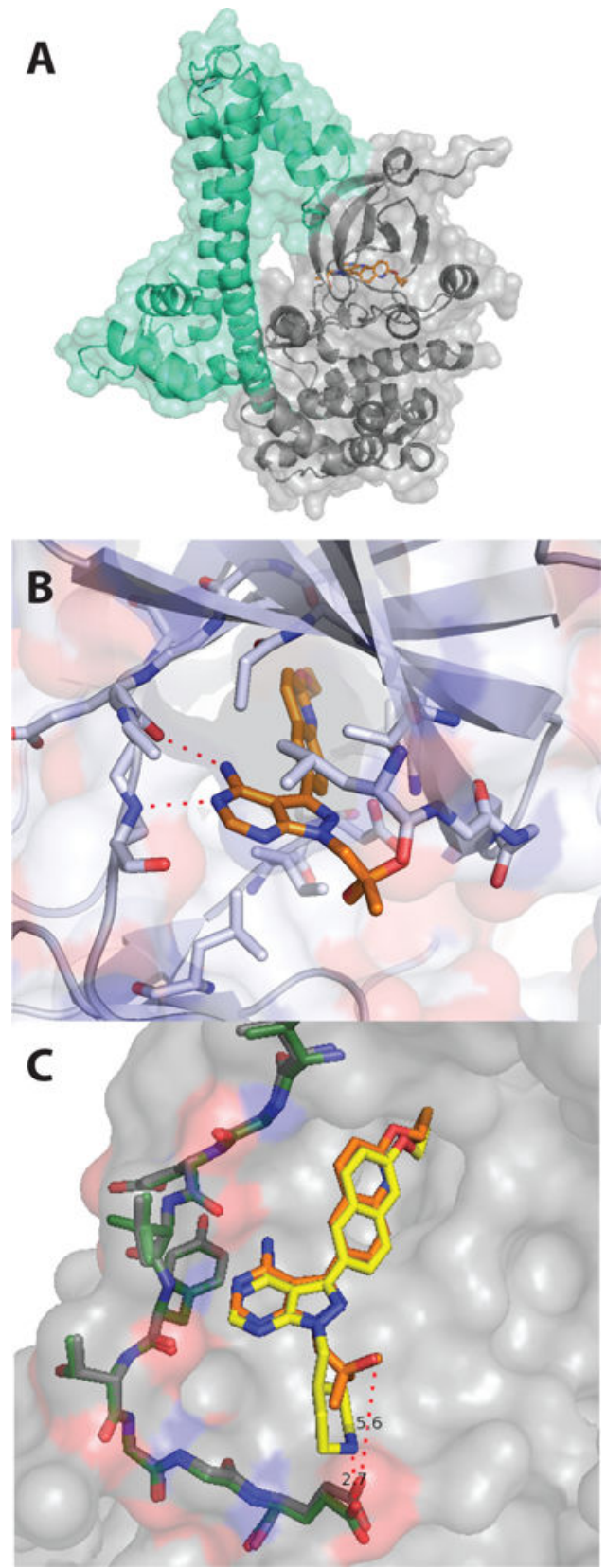

Figure 6.

Structure of the $T g$ CDPK1.33 complex (PDB accession code: 4TZR). (A) Entire view of the 33. $T g C D P K 1$ co-crystal structure. Inhibitor 33 is shown as orange sticks. The CDPK activation domain (CAD) of TgCDPK1 is in mint and the kinase domain is shown in grey. (B) Expanded view of the ATP-binding site from the TgCDPK1.33 complex. The backbone amides of residues Glu129 and Tyr131 in the hinge region (shown as sticks) form two hydrogen bonds (dashed red lines) with the pyrazolopyrimidine scaffold of $\mathbf{3 3}$. The 2cyclopropyloxyquinolin-6-yl $\mathrm{R}_{2}$ group of $\mathbf{3 3}$ is directed towards the Gly128 gatekeeper residue. (C) An overlay of an analog of $\mathbf{1}$ (yellow) bound to TgCDPK1 (PDB accession code: 3SX9) and the $T g \mathrm{CDPK} 1 \cdot 33$ (orange) complex (PDB accession code: 3SX9) 

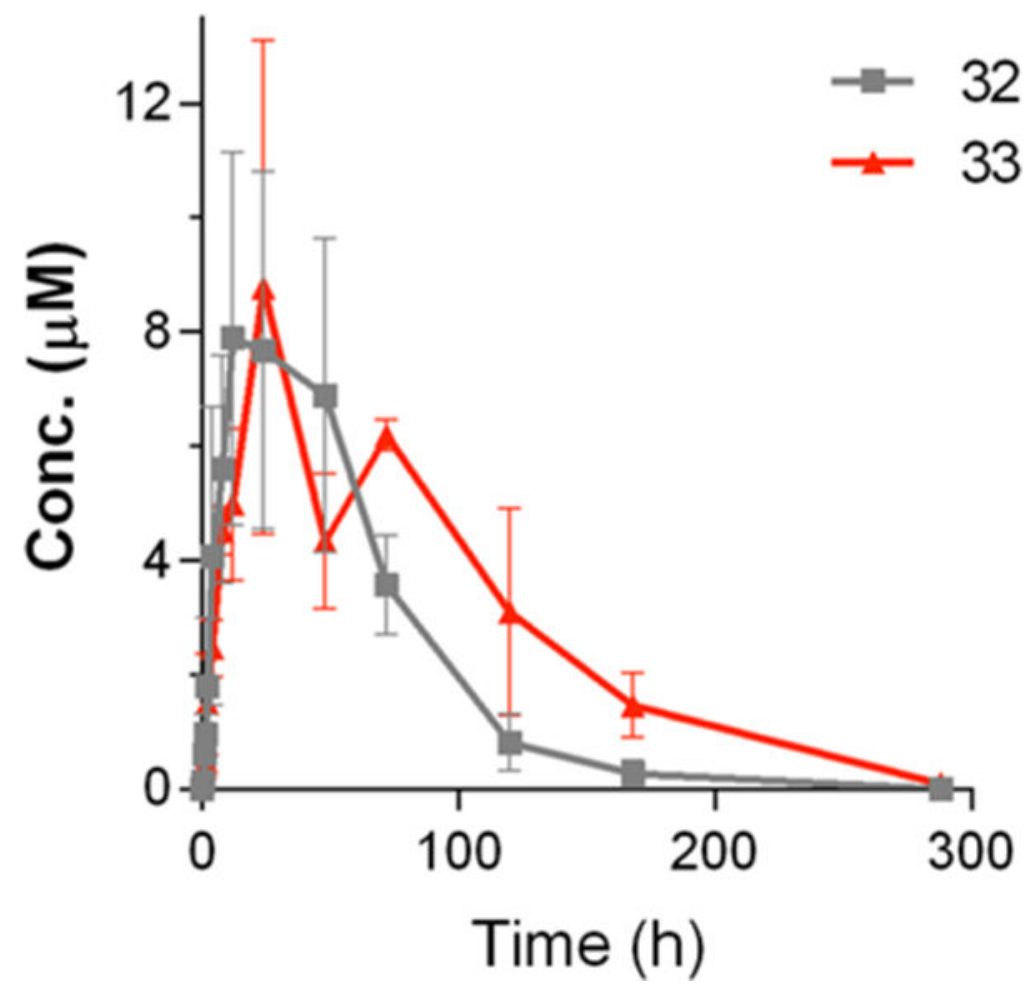

Figure 7.

Calf plasma levels. Comparison of oral PK for compounds $\mathbf{3 2}$ and 33. Each compound was tested in two calves. Compounds $\mathbf{3 2}$ was dosed at $9.3 \mathrm{mg} / \mathrm{kg}$ and compound $\mathbf{3 3}$ was dosed at $10 \mathrm{mg} / \mathrm{kg}$, PO. Each point shows the mean and range of measurements in two calves. 


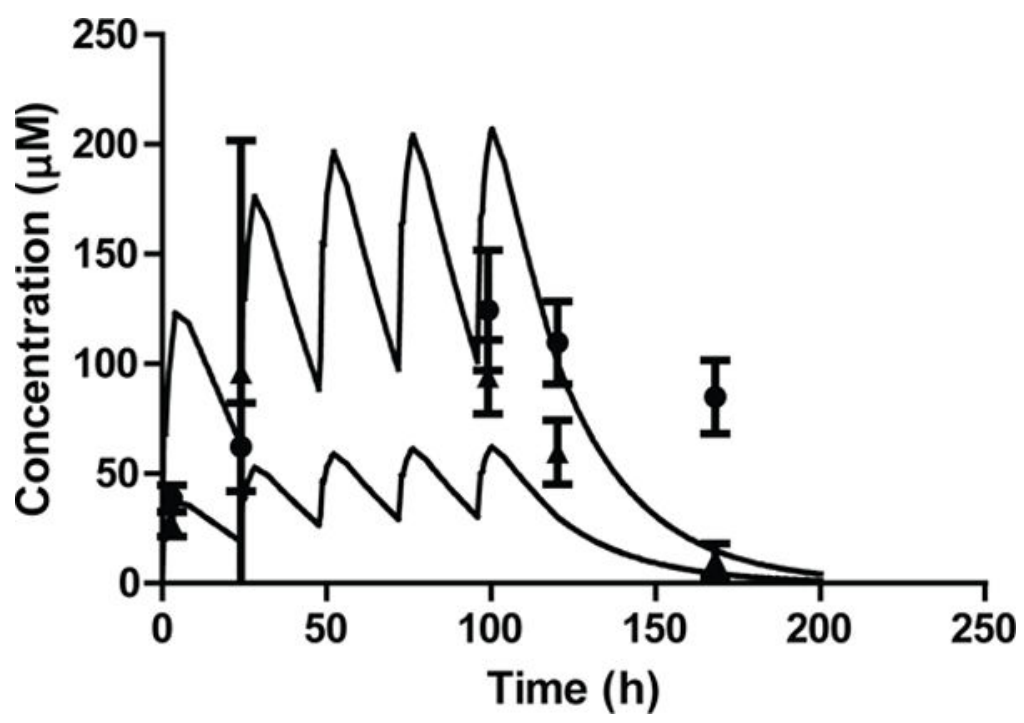

Figure 8.

Exposure to compound $\mathbf{3 2}$ in multiple dose toxicity studies. The concentration profiles of $\mathbf{3 2}$ following $30 \mathrm{mg} / \mathrm{kg}$ and $100 \mathrm{mg} / \mathrm{kg}$ daily doses were simulated based on the single dose 10 $\mathrm{mg} / \mathrm{kg}$ data. The mean observed concentrations $(\mathrm{n}=3)$ with standard deviation are plotted as triangles for $30 \mathrm{mg} / \mathrm{kg}$ dosing and circles for the $100 \mathrm{mg} / \mathrm{kg}$ dosing) with the simulation. 

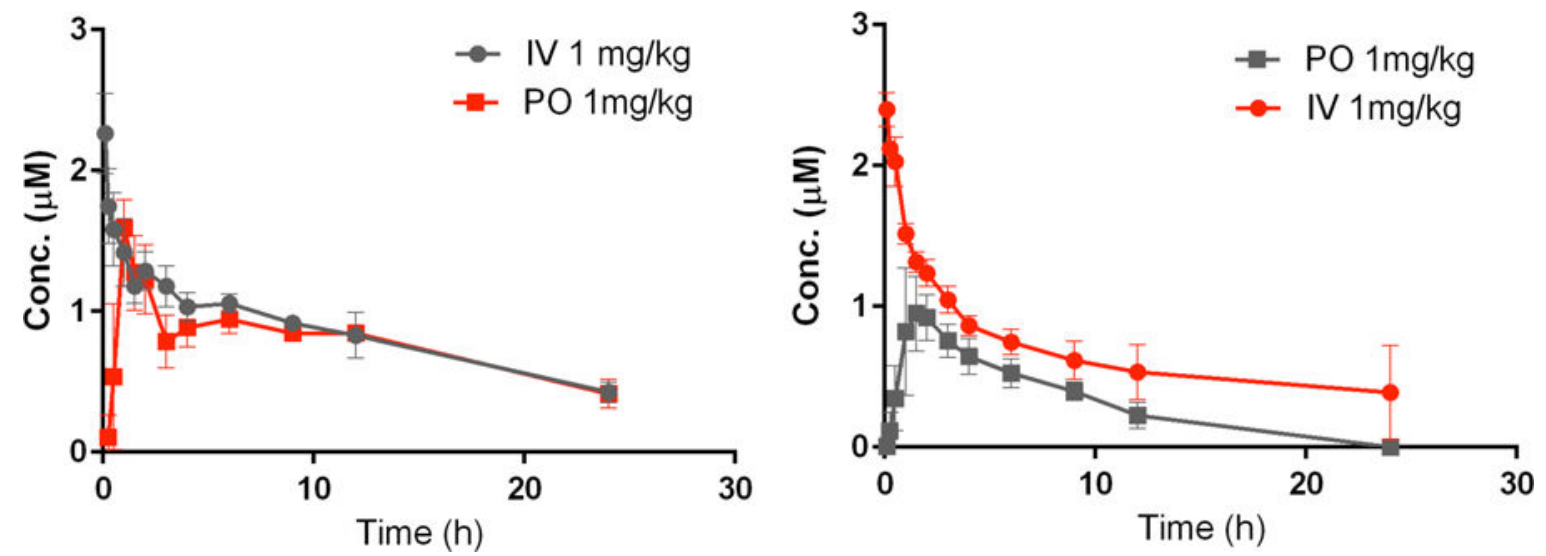

Figure 9.

Plasma concentration time curves for compound $\mathbf{3 2}$ following IV and PO dosing to dogs (left) and monkeys (right). 

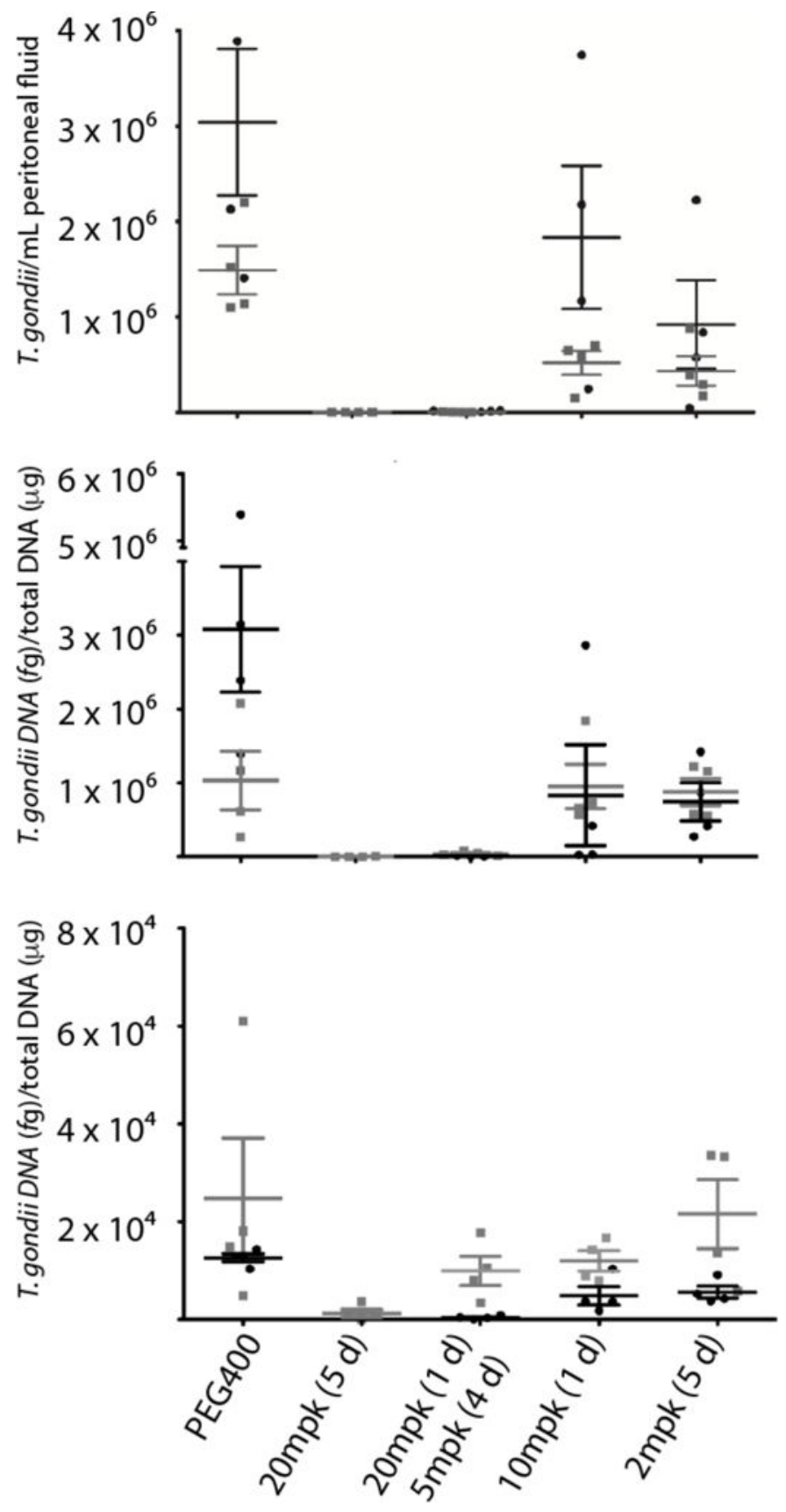

Figure 10.

Inhibitor $\mathbf{3 2}$ is efficacious against acute toxoplasmosis. Efficacy was evaluated by measurement of $T$. gondii in peritoneal fluid (top), spleen (middle), and brain (bottom) in two experiments. Mice were treated daily for 5 days, beginning 2 days after IP infection with $T$. gondii. Mice were analyzed one day after the last dose. Peritoneal fluid was analyzed by fluorescent microscopy and spleen and brain tissue were analyzed by quantitative realtime PCR. Groups consisted of 4 mice. Bars represent the mean and the standard error of the mean. $\mathrm{PEG}=$ polyethylene glycol; $\mathrm{mpk}=\mathrm{mg} / \mathrm{kg}$. 


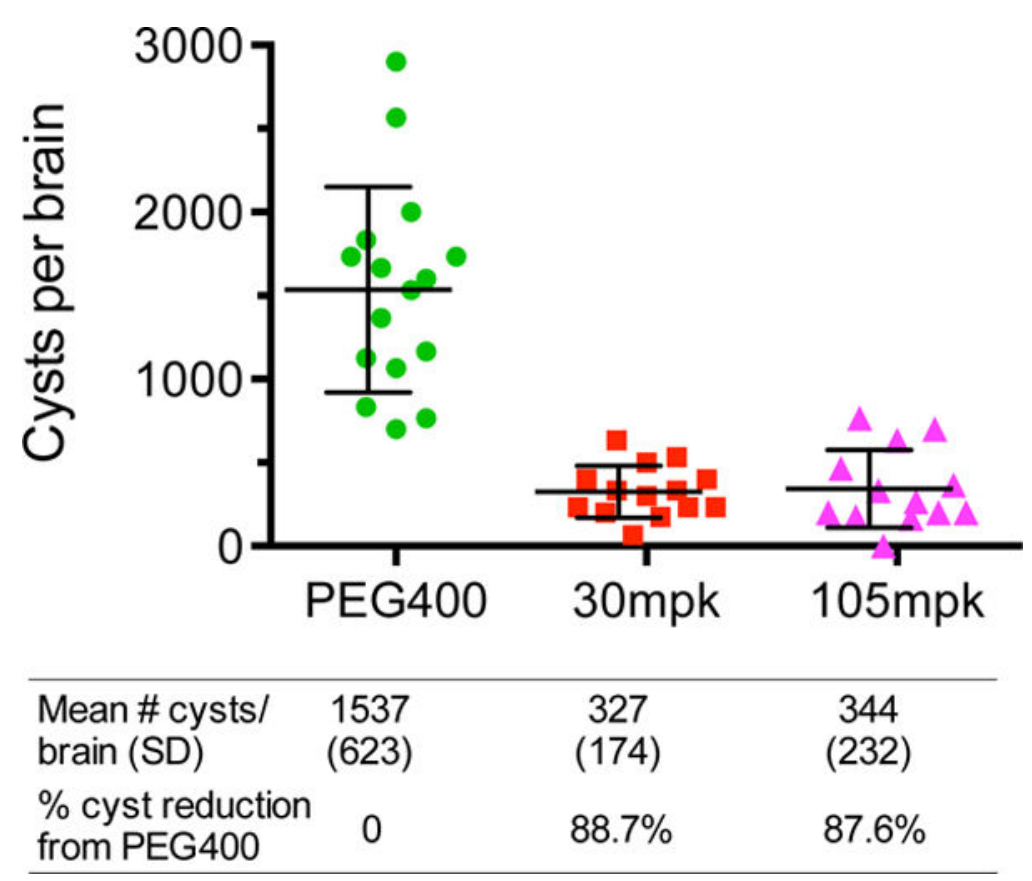

Fig. 11.

Inhibitor 32 is efficacious against latent $T$. gondii infection. 32 reduced the number of $T$. gondii cysts per brain compared to a vehicle control. Five weeks after being inoculated by the ME49 T. gondii strain, mice were treated once daily for 14 days via oral gavage with 30 $\mathrm{mg} / \mathrm{kg}$ of $\mathbf{3 2}$ or PEG400 vehicle control. A group of mice was also treated twice-days 1 and 7 -via oral gavage with $105 \mathrm{mg} / \mathrm{kg}$ of 32. Two weeks after the final drug treatment, mice were sacrificed and the number of brain cysts was determined. The number of cysts per brain was $>85 \%$ lower for both dosing regimens of $\mathbf{3 2}$ relative to a vehicle control. Bars represent the mean and the standard error of the mean. $\mathrm{PEG}=$ polyethylene glycol; $\mathrm{mpk}=$ $\mathrm{mg} / \mathrm{kg}$. 

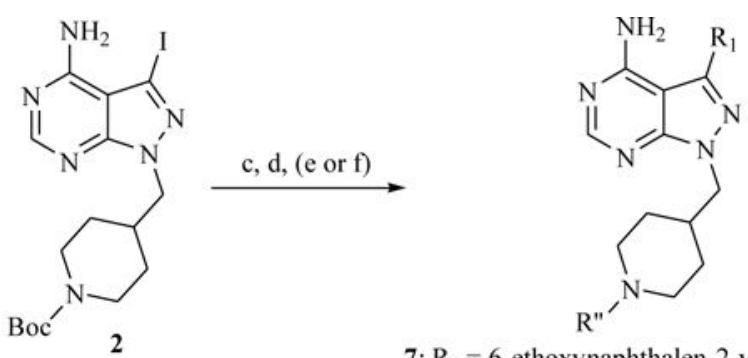

7: $\mathrm{R}_{\mathrm{I}}=$ 6-ethoxynaphthalen-2-yl, $\mathrm{R}^{\prime \prime}=$ isopropyl

8: $\mathrm{R}_{1}=6$-ethoxynaphthalen-2-yl, $\mathrm{R}^{\prime \prime}=$ acetyl
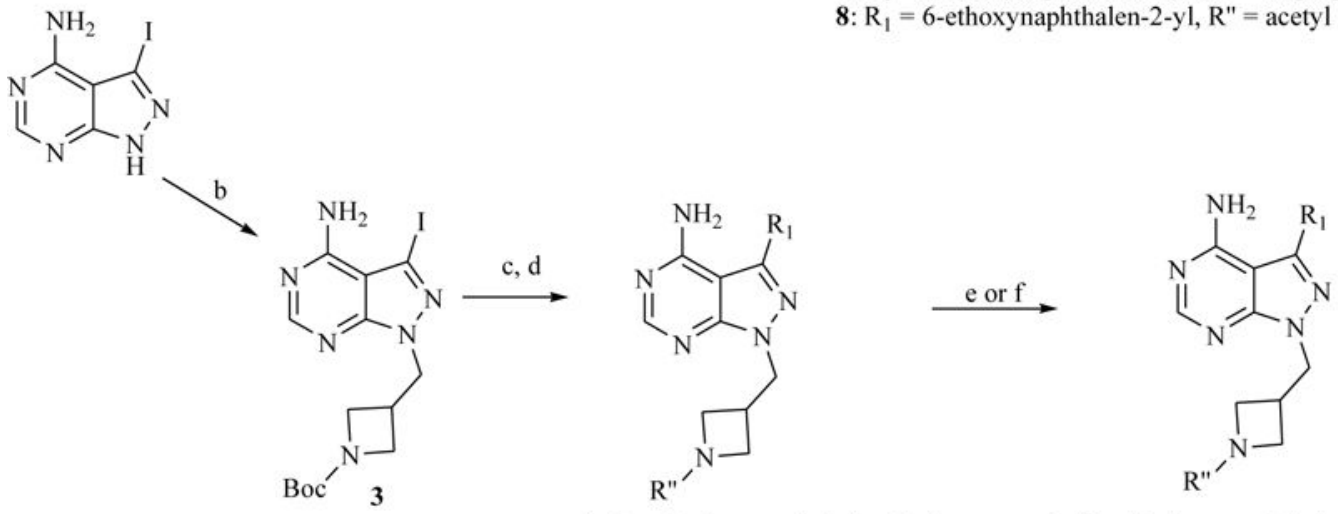

5: $\mathrm{R}_{1}=6$-ethoxynaphthalen-2-yl, $\mathrm{R}^{\prime \prime}=\mathrm{H}$

6: $R_{1}=6$-ethoxynaphthalen-2-yl, $R^{\prime \prime}=$ methyl, 9: $\mathrm{R}_{1}=6$-ethoxynaphthalen-2-yl, $\mathrm{R}^{\prime \prime}=$ acetyl

Scheme 1.

a) $\mathrm{N}$-Boc-4-piperidinemethanol mesylate, $\mathrm{Cs}_{2} \mathrm{CO}_{3}$, DMF, $80{ }^{\circ} \mathrm{C}$; b) $\mathrm{N}$-Boc-3azetidinemethanol mesylate, $\mathrm{Cs}_{2} \mathrm{CO}_{3}$, DMF, $80{ }^{\circ} \mathrm{C}$; c) $\mathrm{Na}_{2} \mathrm{CO}_{3}, \mathrm{Pd}\left(\mathrm{PPh}_{3}\right)_{4}$, 6-ethoxy-2naphthaleneboronic acid, $\mathrm{H}_{2} \mathrm{O} / \mathrm{DME}, 80^{\circ} \mathrm{C}$ (microwave); d) TFA/ $\mathrm{CH}_{2} \mathrm{Cl}_{2}$ (1:1); e) sodium methoxide in $\mathrm{MeOH}$, then $2 \% \mathrm{AcOH}$, formaldehyde or acetone, $\mathrm{NaBH}_{3} \mathrm{CN}$; f) $\mathrm{Ac}_{2} \mathrm{O}$, TEA, DMF. 


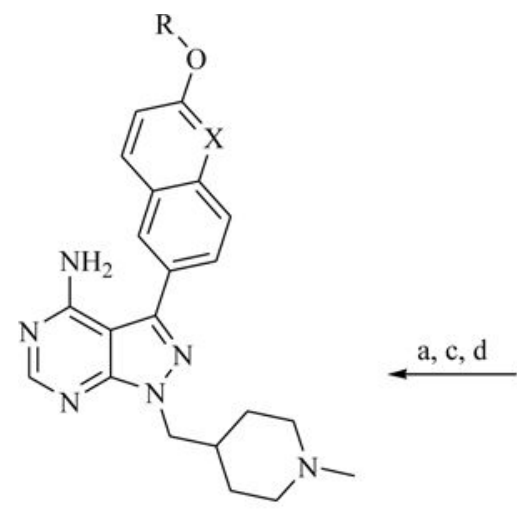

11, 12: $\mathrm{X}=\mathrm{CH}$

17-19: $X=N$

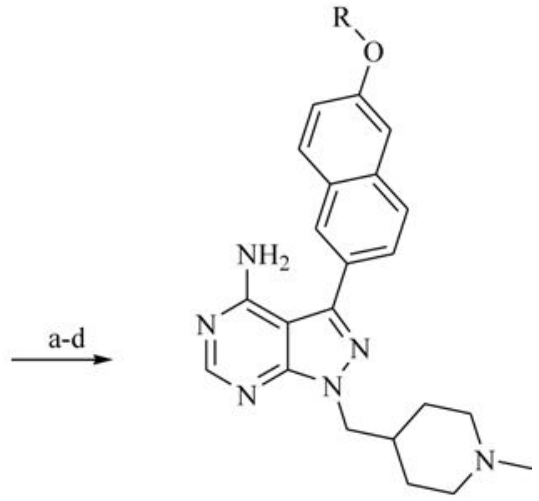

10, 13-16

Scheme 2.

a) aryl boronate ester, $\mathrm{K}_{3} \mathrm{PO}_{4} / \mathrm{Na}_{2} \mathrm{CO}_{3}, \mathrm{PdCl}_{2}$ (dppf), 1,4-Dioxane: $\mathrm{H}_{2} \mathrm{O}$ or DME: $\mathrm{H}_{2} \mathrm{O}, 80{ }^{\circ} \mathrm{C}$ (microwave); b) alkyl halide or epoxide, $\mathrm{NaH}_{2} \mathrm{PO}_{4}: \mathrm{K}_{2} \mathrm{CO}_{3}(1: 1)$, DMF, $60{ }^{\circ} \mathrm{C}$; c) TFA/ $\mathrm{CH}_{2} \mathrm{Cl}_{2}(1: 1)$; d) sodium methoxide in $\mathrm{MeOH}$, then $2 \% \mathrm{AcOH}$, formaldehyde, $\mathrm{NaBH}_{3} \mathrm{CN}$. Compound 4 was synthesized according to a previously reported procedure. ${ }^{19}$ 
<smiles>Nc1ncnc2[nH]nc(I)c12</smiles><smiles>[R]c1nn([R2])c2ncnc(N)c12</smiles>

Scheme 3.

a) alkyl halide or alkyl mesylate, $\mathrm{Cs}_{2} \mathrm{CO}_{3}$, DMF, $80^{\circ} \mathrm{C}$; b) epoxide, $\mathrm{NaH}_{2} \mathrm{PO}_{4}: \mathrm{K}_{2} \mathrm{CO}_{3}(1: 1)$, DMF, $80{ }^{\circ} \mathrm{C}$; c) aryl boronate ester, $\mathrm{K}_{3} \mathrm{PO}_{4}$ or $\mathrm{Na}_{2} \mathrm{CO}_{3}, \mathrm{PdCl}_{2}(\mathrm{dppf})$ or $\mathrm{Pd}\left(\mathrm{PPh}_{3}\right)_{4}, 1,4-$ Dioxane: $\mathrm{H}_{2} \mathrm{O}$ or DME: $\mathrm{H}_{2} \mathrm{O}, 80{ }^{\circ} \mathrm{C}$ (microwave). 


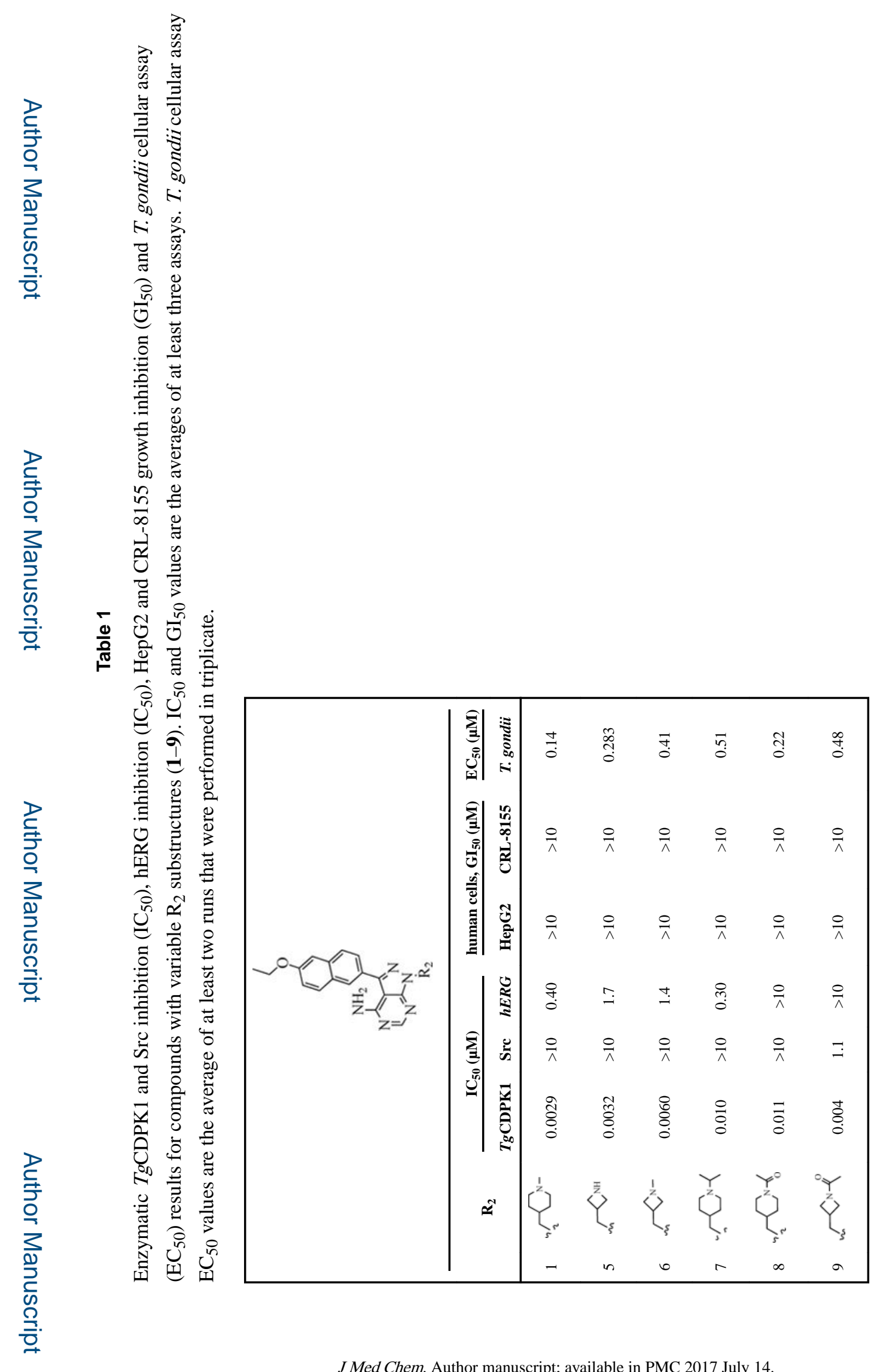




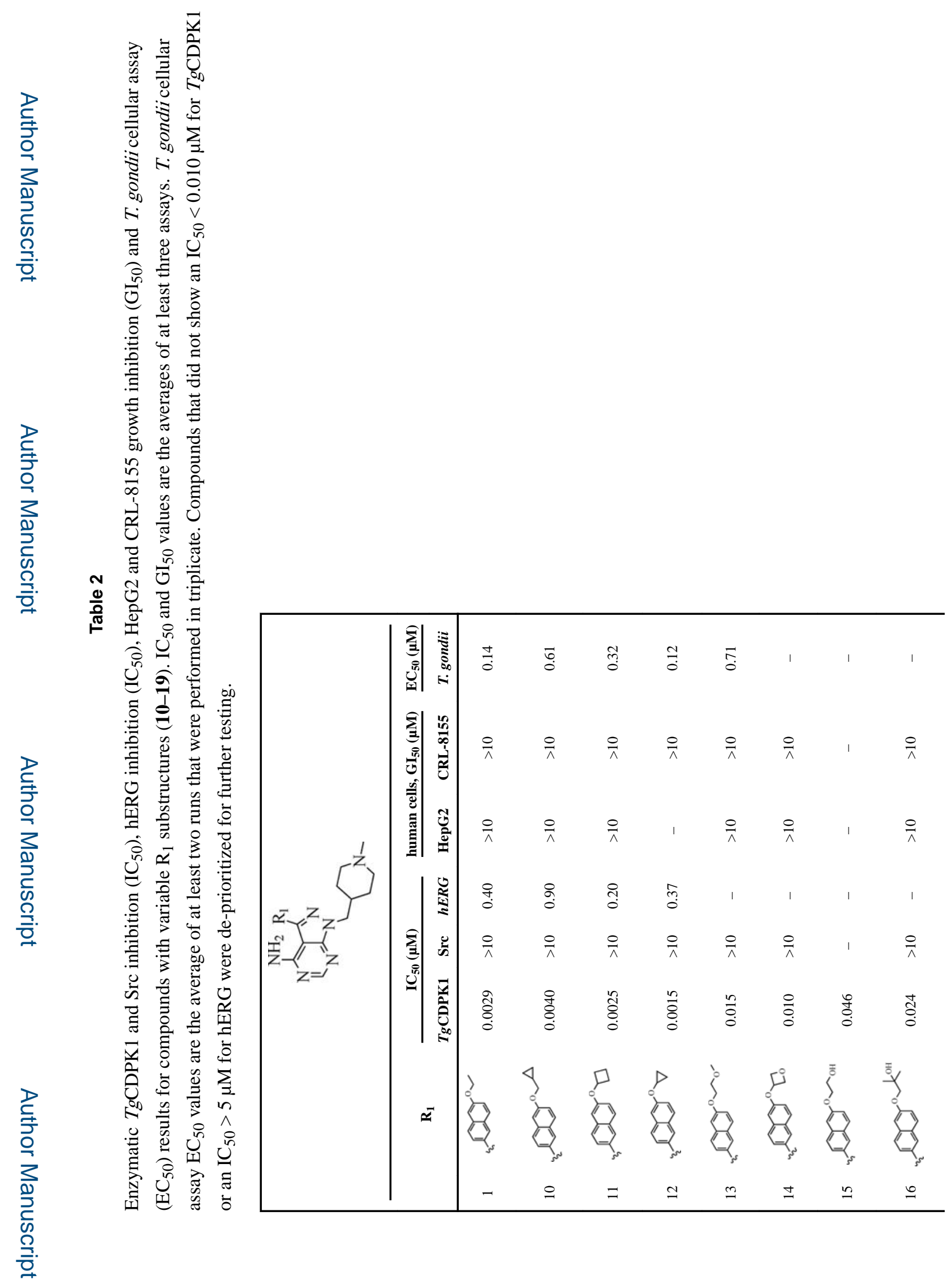

J Med Chem. Author manuscript; available in PMC 2017 July 14. 


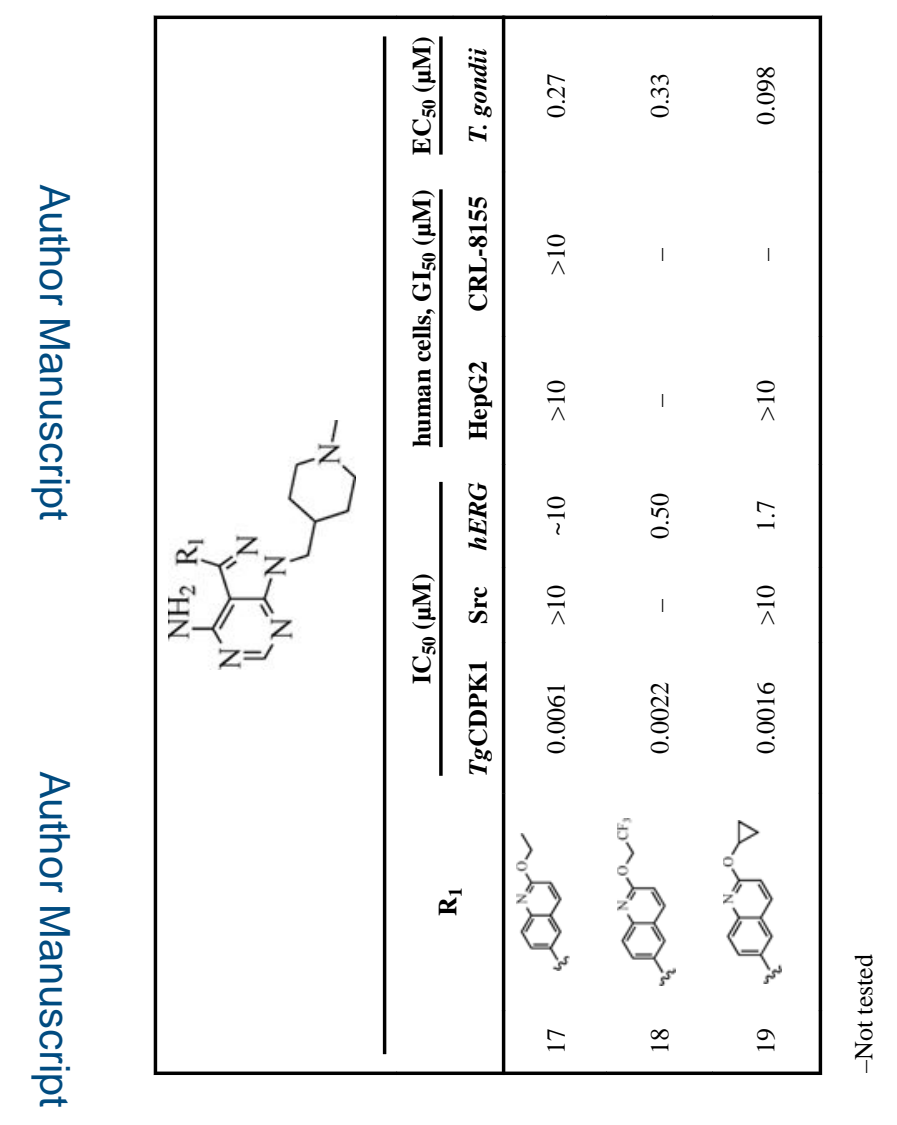

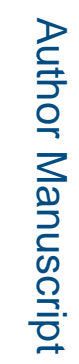

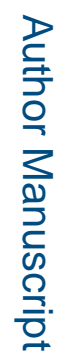




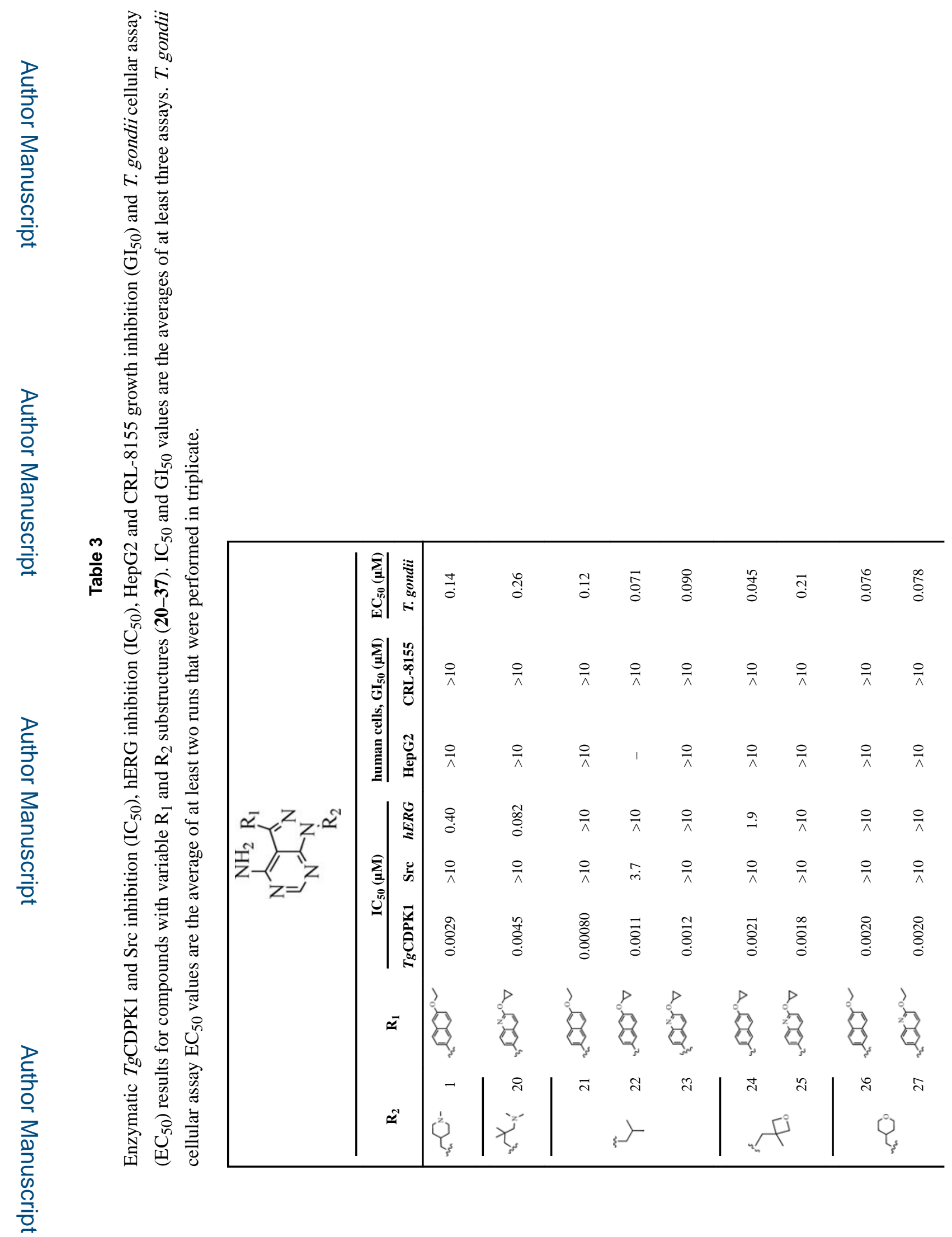

J Med Chem. Author manuscript; available in PMC 2017 July 14. 


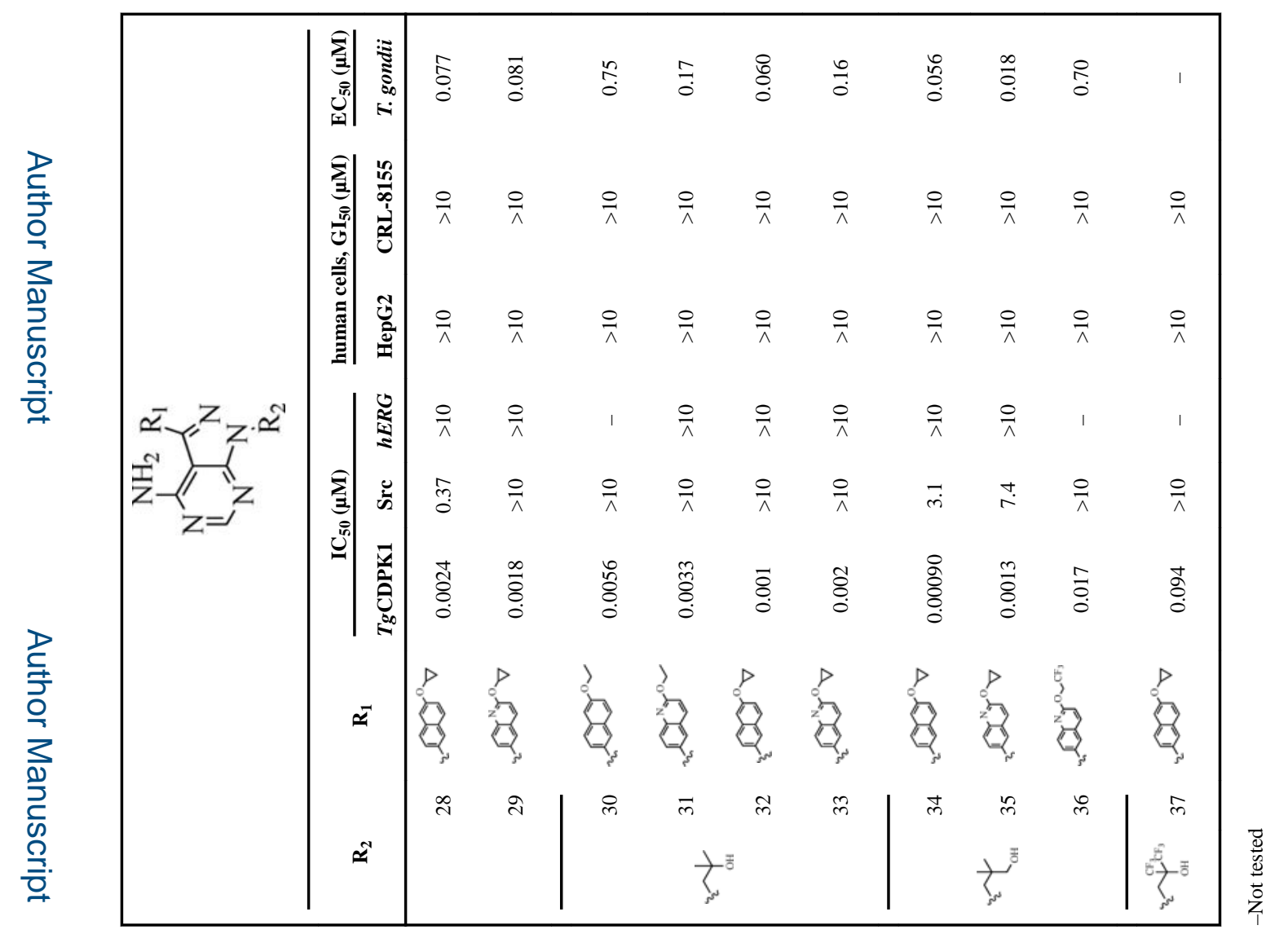

로을

로을 


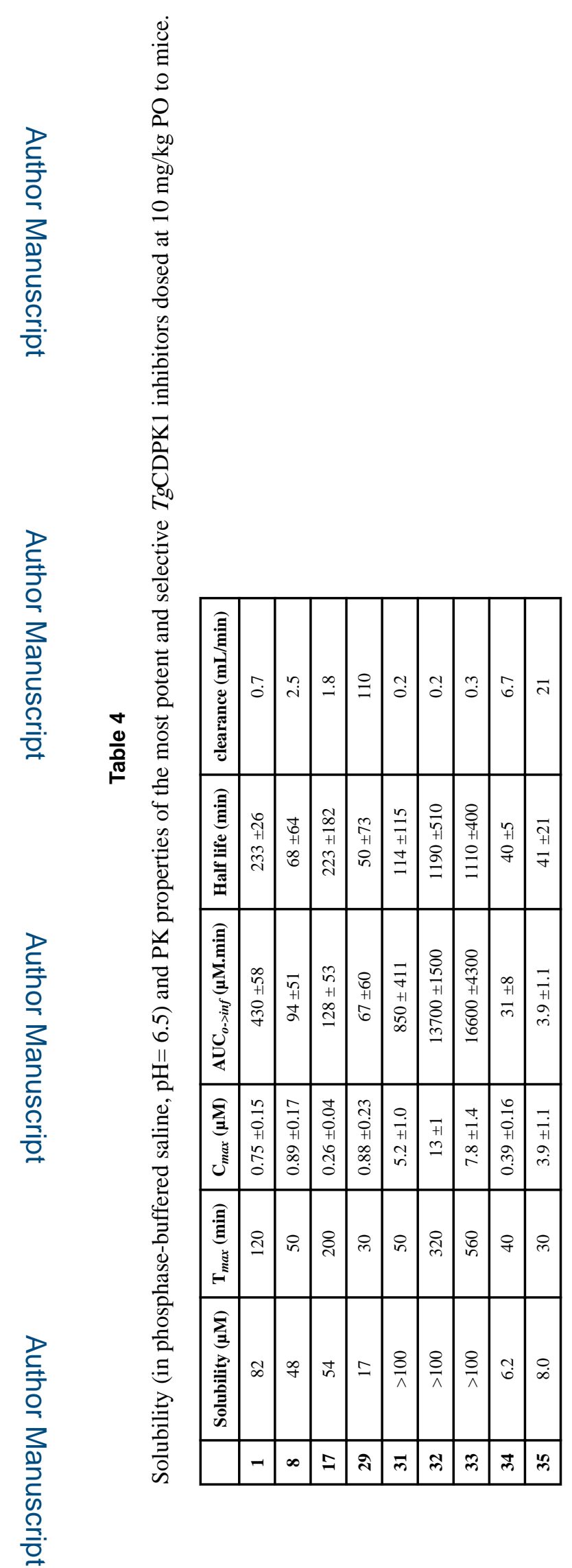

J Med Chem. Author manuscript; available in PMC 2017 July 14. 
Table 5

In vivo pharmacokinetic parameters of $\mathbf{3 2}$ and $\mathbf{3 3}$ in rats following IV administration of $5 \mathrm{mg} / \mathrm{kg}$. Data is shown as mean and range between animals.

\begin{tabular}{|c|c|c|c|c|}
\hline & $A U C(\boldsymbol{h} \boldsymbol{\mu} \mathbf{~ m o l} / \mathbf{L})$ & $\boldsymbol{C L}(\mathbf{m L} / \mathbf{h r} / \mathbf{k g})$ & $\boldsymbol{V}_{s s}(\boldsymbol{L} / \mathbf{k g})$ & $\boldsymbol{T}_{\mathbf{1 / 2}}(\boldsymbol{h r})$ \\
\hline $\mathbf{3 2}$ & $167(160-175)$ & $77(73-80)$ & $0.91(0.89-0.93)$ & $9.6(9.5-9.7)$ \\
\hline 33 & $45(31-59)$ & $310(216-412)$ & $5.8(4.1-7.5)$ & $13(12.6-13.4)$ \\
\hline
\end{tabular}




\section{Table 6}

In vivo pharmacokinetic parameters of $\mathbf{3 2}$ and $\mathbf{3 3}$ in calves following PO administration of $10 \mathrm{mg} / \mathrm{kg}$ of $\mathbf{3 2}$ and $9.3 \mathrm{mg} / \mathrm{kg}$ of 33. Data are shown as the mean and range between animals.

\begin{tabular}{|c|c|c|c|c|}
\hline & AUC $(\boldsymbol{h} * \boldsymbol{\mu ~ m o l} / \mathbf{L})$ & $\boldsymbol{C L} / \boldsymbol{F}(\boldsymbol{m L} / \mathbf{h r} / \mathbf{k g})$ & $V / F(\boldsymbol{L} / \mathbf{k g})$ & $\boldsymbol{t 1 / 2}(\boldsymbol{h r})$ \\
\hline 32 & $588(353-825)$ & $52(31-72)$ & $1.5(1.3-1.8)$ & $23(17-28)$ \\
\hline $\mathbf{3 3}$ & $849(607-1091)$ & $30(22-39)$ & $2.3(1.4-3.2)$ & $51(46-56)$ \\
\hline
\end{tabular}




\section{Table 7}

In vivo pharmacokinetic parameters of $\mathbf{3 2}$ following IV and PO administration of $1 \mathrm{mg} / \mathrm{kg}$ to dogs and monkeys ( $\mathrm{n}=3$ for each). Data is show as mean and standard deviation.

\begin{tabular}{|c|c|c|c|c|}
\hline & AUC $(\boldsymbol{h} * \boldsymbol{\mu ~ m o l} / \mathbf{L})$ & $C L(\mathbf{m L} / \mathbf{h r} / \mathrm{kg})$ & $V s s(L / k g)$ & $t \mathbf{t} / \mathbf{2}(\mathbf{h r})$ \\
\hline IV & $11200 \pm 1100$ & $90 \pm 10$ & $1.7 \pm 0.1$ & 13.2 \\
\hline PO & $9620 \pm 1350$ & & & \\
\hline \multicolumn{5}{|c|}{ Mogs } \\
\hline IV & $8720 \pm 3400$ & $130 \pm 50$ & $1.8 \pm 0.3$ & 9.6 \\
\hline PO & $5730 \pm 1500$ & & & \\
\hline
\end{tabular}

